\title{
SURVEY OF RECENT REPORTED CASES IN REAL PROPERTy LAW
}

\author{
BRIAN C. CRIST* \\ AARON AFT ${ }^{* *}$ \\ GREGORY C. TOUNEY ${ }^{* * *}$
}

INTRODUCTION

This Article examines the reported decisions during the survey period ${ }^{1}$ of the Indiana Supreme Court (hereinafter the "Supreme Court"), Court of Appeals of Indiana (hereinafter the "Court of Appeals"), and the Indiana Tax Court (hereinafter the "Tax Court") concerning real property issues.

\section{LIENS AND FORECLOSURES}

During the survey period, the Court of Appeals published opinions in five cases that concerned the establishment, priority and foreclosure of real property liens.

\section{A. Subordination Agreements and Modification of Lien Priority}

In Co-Alliance, LLP v. Monticello Farm Service, Inc., ${ }^{2}$ the Court of Appeals considered the impact of a subordination agreement between creditors with different lien priorities. ${ }^{3}$ Co-Alliance arose from certain agricultural borrowers' pledge of their 2010 crops and other farm products and equipment as collateral to secure loans from three different creditors, whose security interests were perfected in the order of first creditor, second creditor, and third creditor (collectively, the "Creditors"). ${ }^{4}$ On June 25, 2010, first creditor and third creditor entered into an agreement (the "Additional Finance Agreement")

* Brian C. Crist is a partner in Ice Miller LLP's real estate section. He received a B.A. in History and Economics from the University of Missouri in 1994 and his J.D. from Vanderbilt University in 1997.

** Aaron Aft is an associate attorney in Ice Miller LLP's real estate section. He received his B.A. in Philosophy from Indiana University, Bloomington in 2004 and his J.D. from the Indiana University Maurer School of Law in 2011.

*** Gregory C. Touney is an associate attorney in Ice Miller LLP's real estate section. He received a B.A. in History from the University of Notre Dame in 2007 and his J.D. from the Indiana University Maurer School of Law in 2011. The authors wish to thank their friends and colleagues in the real estate section of Ice Miller LLP, and Ice Miller's 2014 summer class for their assistance with this Article.

1. The survey period is from October 1, 2013 to September 30, 2014.

2. 7 N.E.3d 355 (Ind. Ct. App. 2014).

3. Id. at 356 .

4. Id. at 357. First creditor is Farmers Bank \& Trust. Second creditor is Co-Alliance, LLP. Third creditor is Monticello Farm Service, Inc. 
whereby third creditor agreed to finance the borrowers' 2010 crops. $^{5}$ In consideration of the additional financing, first creditor agreed to subordinate its interest in the 2010 crops to third creditor's interests in the 2010 crops $^{6}{ }^{6}$ The borrowers filed for bankruptcy in November 2010. ${ }^{7}$ In December 2011, the borrowers and first creditor waived their respective rights to claim $\$ 181,000$ of the 2010 crop proceeds. ${ }^{8}$ First creditor then assigned its remaining interest to second creditor, subject to any rights and interests that third creditor had under the Additional Finance Agreement. ${ }^{9}$ Second and third creditors then waived their interests in any 2010 crop proceeds exceeding $\$ 181,000 .^{10}$ In February 2011, first creditor sought foreclosure and a monetary judgment against borrowers, also naming second creditor and third creditor as defendants due to their interests in the borrowers' property. ${ }^{11}$ Third creditor answered the complaint and crossclaimed against the other creditors. ${ }^{12}$ Second creditor then counterclaimed against third creditor, asserting that it had priority over third creditor's lien. ${ }^{13}$ Second and third creditor each moved for partial summary judgment. ${ }^{14}$ In October 2012, the trial court determined that third creditor was entitled to the first claim on first creditor's $\$ 181,000$, denied second creditor's motion, and ordered the clerk to hold the funds. ${ }^{15}$ Second creditor appealed the trial courts' decision. ${ }^{16}$

The sole issue the Court of Appeals considered was whether "the trial court properly determined that the subordination agreement gave [third creditor] first claim on the remaining $\$ 181,000$ in 2010 crop proceeds." $" 17$ The Court of Appeals first observed that "subordination agreements are nothing more than contractual modifications of lien priorities."18 In a situation where not all lienholders participate in a subordination agreement, the Court of Appeals held a court must interpret a subordination agreement in this situation as a partial subordination/partial assignment, which is the approach followed by a majority of states. ${ }^{19}$ The Court of Appeals also found that the Additional Finance
5. Id.
6. $I d$.
7. $I d$.
8. $I d$.
9. $I d$.
10. Id.
11. Id. at 358 .
12. Id.
13. Id.
14. Id.
15. Id.
16. Id. The second creditor appealed the trial court's initial ruling, but the appeal was dismissed because the trial court's order was not yet final. After the trial court disbursed the $\$ 180,000$ to third creditor, second creditor appealed.
17. Id.
18. Id.
19. Id. at 359 . 
Agreement between first creditor and third creditor functioned as a partial assignment of first creditor's first lien priority status, as it was clear from the Additional Finance Agreement that third creditor was extending additional credit to finance borrower's 2010 crop, in part, based upon first creditor's assurance that third creditor would be first in line for payment. ${ }^{20}$ Accordingly, the Court of Appeals upheld the trial court's determination that the Additional Finance Agreement assigned the maximum amount of the first creditor's lien to third creditor. ${ }^{21}$ By so limiting third creditor's priority, second creditor was "neither burdened or benefitted by the subordination agreement." 22

The Court of Appeals considered but rejected the second creditor's argument that the "complete subordination" approach adopted by a minority of states should be the controlling standard in Indiana, as the complete subordination standard would have elevated second creditor's lien to first lien status even though second creditor gave no consideration for the additional financing and would have received a windfall. ${ }^{23}$

\section{B. Collection of Costs in Enforcing a Judgment}

In Stoffel v. JPMorgan Chase Bank, N.A., ${ }^{24}$ the Court of Appeals considered two questions: (1) under what circumstances can a creditor collect additional costs incurred in enforcing a previously entered judgment, and (2) what type of evidence is admissible to prove the creditor incurred additional costs. ${ }^{25}$ Stoffel concerned a lender who filed an action seeking judgment on a promissory note and foreclosure of a mortgage granted by a property owner. ${ }^{26}$ Lender and property owner later filed an Agreed Judgment and Entry and Decree of Foreclosure (hereinafter the "Judgment") granting the lender a personal judgment against the property owner in the amount of $\$ 139,907.82 .{ }^{27}$ The Judgment further granted lender the right to collect other costs incurred from the time that lender and property owner agreed upon the Judgment to the date of the sheriff's sale. ${ }^{28}$ The Judgment was assigned to a new lender that credit bid the Judgment and additional costs incurred for a total of $\$ 152,121.72$, and purchased the property at the sheriff's sale with the credit bid. ${ }^{29}$ The new lender then filed its satisfaction and release of the Judgment with the trial court. ${ }^{30}$ Property owner later filed a motion to compel the difference between new lender's credit bid

20. Id.

21. Id. at 361 .

22. Id. at 360 .

23. Id.

24. 3 N.E.3d 548 (Ind. Ct. App. 2014).

25. Id. at 550 .

26. Id.

27. Id. at 550-51.

28. Id. at 550 .

29. Id. at 551 .

30. Id. 
$(\$ 152,121.72)$ and the face amount of the Judgment $(\$ 139,907.82)$, asserting that he was entitled to the difference. ${ }^{31}$ The trial court held a hearing on the property owner's motion and new lender submitted affidavits from its vice president and attorney to support the additional costs incurred after the Judgment was entered. ${ }^{32}$ Over property owner's objections, the trial court admitted the affidavits and denied property owner's motion to compel payment of the alleged surplus. ${ }^{33}$ Property owner appealed the trial court's judgment. ${ }^{34}$

The Court of Appeals held that the trial court's denial of the property owner's motion to compel was not a modification of the Judgment since the terms of the Judgment left certain costs to be determined; thus, the amount of the Judgment was an issue "squarely before the court" on property owner's motion to compel. ${ }^{35}$ With respect to the admission of new lender's evidence submitted to support the additional costs of the Judgment, the Court of Appeals determined that the trial court abused its discretion. ${ }^{36}$ The Court of Appeals held the rules of evidence applied to the property owner's motion to compel, even though the proceeding was equitable in nature. ${ }^{37}$ Applying the rules of evidence, the Court of Appeals found that new lender's affidavits were inadmissible hearsay and not self-authenticating, ${ }^{38}$ and ordered the trial court to enter judgment in favor of the property owner for the difference between the credit bid and the face amount of the Judgment.

\section{Full Faith and Credit of Foreign Judgments and Indiana Mortgages}

In Setree v. River City Bank, ${ }^{39}$ the Court of Appeals considered whether an Indiana court must give full faith and credit to a Kentucky court's judgment with respect to borrowers' default under an Indiana promissory note and mortgage. ${ }^{40}$ In Setree, borrowers obtained two loans from lender, each secured by separate mortgages on various properties in Kentucky and Indiana. ${ }^{41}$ Borrowers obtained a third loan (hereinafter the "Indiana Loan") from lender, secured by a new

\section{Id.}

32. Id. The affidavits asserted that additional costs had been incurred from the time of the Judgment to the time the sheriff's sale was held. Fannie Mae also submitted a letter from an individual that stated how the bid had been calculated and that identified post-judgment costs and advances. However, the letter did not include information sufficient to discern the affiant's employer, job description or address.

33. Id.

34. Id.

35. Id. at 553 .

36. Id. at 555 .

37. Id.

38. Id. at 554. Interestingly, new lender did not dispute the affidavits were hearsay and were not self-authenticating.

39. 10 N.E.3d 30 (Ind. Ct. App. 2014).

40. Id. at 31 .

41. Id. 
mortgage on Indiana real estate (hereinafter the "Indiana Property"). ${ }^{42}$ All of the loans included cross-default provisions. ${ }^{43}$ Borrowers failed to pay Indiana real estate taxes on the Indiana Property, which triggered a default under the Indiana Loan. ${ }^{44}$ Lender sued borrowers in Kentucky on the first two loans based upon the Indiana Loan default and the cross-default provisions of the Kentucky loans. ${ }^{45}$ The Kentucky court ruled that borrowers had defaulted under the Indiana Loan (thus triggering the cross-default provisions of the other loans), and issued its judgment and decree foreclosing lender's mortgages on the Kentucky real estate (the "Kentucky Judgment"). ${ }^{46}$ Following entry of the Kentucky Judgment, lender brought a separate lawsuit in Indiana, seeking a judgment and decree of foreclosure as to the Indiana Property. ${ }^{47}$ Both parties filed summary judgment motions with respect to the enforcement of the Kentucky Judgment. ${ }^{48}$ After a hearing on each motion, the trial court entered summary judgment in favor of lender based upon principles of full faith and credit, and concluding that the Kentucky Judgment was res judicata as to borrowers' default under the Indiana Loan and the related mortgage. ${ }^{49}$

The Court of Appeals affirmed, concluding the Full Faith and Credit Clause of the United States Constitution ${ }^{50}$ and Indiana statute ${ }^{51}$ required the Kentucky Judgment be afforded full faith and credit, so long as the Kentucky court had personal and subject matter jurisdiction over the parties. The Court of Appeals also relied upon the United States Supreme Court's decision in Durfee v. Duke, ${ }^{52}$ which recognized the principle that once a matter has been fully litigated and judicially determined in one state, it cannot be retried in another state in litigation between the same parties. ${ }^{53}$ The Court of Appeals rejected borrowers' argument that real property is unique; thus, requiring an exception to Durfee. Instead, the Court of Appeals ruled that the Kentucky Judgment had already conclusively established Borrowers' default under the Indiana Loan, and that the Kentucky Judgment was required to be given full faith and credit in Indiana. ${ }^{54}$

After determining the Kentucky Judgment was entitled to full faith and credit, the Court of Appeals concluded res judicata was not applicable to the Kentucky Judgment, as the issue before the trial court was "more properly

42. Id.

43. Id.

44. Id. at 32 .

45. Id. at 32-33.

46. Id.

47. Id.

48. Id.

49. Id. at 34 .

50. U.S. CONST. art. IV, $\S 1$.

51. IND. CODE $\S 34-39-4-3$ (2014).

52. 375 U.S. 106 (1963).

53. Id. at 108 .

54. Setree v. River City Bank, 10 N.E.3d 30, 36 (Ind. Ct. App. 2014). 
defined as issue preclusion" rather than claim preclusion. ${ }^{55}$ Issue preclusion requires the establishment of five elements:

(1) at least one party to be bound in the second case must have been a party in the first case; (2) the issue in the second case must be the same as the issue in the first case; (3) the issue must have been actually litigated; (4) the issue was actually decided in that action; and (5) the decision on the issue in the prior action must have been necessary to the court's judgment and adverse to the part to be bound. ${ }^{56}$

Given the same issues between the same parties were decided in the Kentucky Judgment, the Court of Appeals concluded issue preclusion prevented borrowers from litigating whether the failure to pay property taxes on the Indiana Property triggered defaults under the Indiana Loans and Indiana mortgages. ${ }^{57}$

\section{Default Judgment in Residential Mortgage Foreclosure}

In Kretschmer v. Bank of America, N.A. ${ }^{58}$ the Court of Appeals considered the standard applicable to a motion to set aside a default judgment in a residential foreclosure action under Rule 60(B) of the Indiana Rules of Trial Procedure. ${ }^{59}$ In Kretschmer, the lender obtained a default judgment against a residential property owner after the property owner failed to answer the lender's foreclosure complaint. $^{60}$ The property owner timely filed a Rule 60 (B) motion to set aside the judgment, claiming that he did not file an answer because he had contacted the lender's counsel and "informed someone at [lender's foreclosure] counsel's office that his house was in a short sale" and "was told [by someone in lender's foreclosure counsel's office] not to worry about anything and to continue with the short sale." ${ }^{61}$ As a result of his reliance on the phone conversation, the property owner alleged that the lender should be collaterally estopped from obtaining a default judgment, as lender failed to respond to the property owner's two short sale offers. ${ }^{62}$ The trial court denied the property owner's motion. ${ }^{63}$

The Court of Appeals reversed the trial court's decision, holding the property owner satisfied the requirements of Rule 60(B) ${ }^{64}$ The Court of Appeals observed that to set aside a default judgment, a litigant must establish the default judgment against him was the result of his excusable neglect and must allege a

55. Id. at 37 .

56. Id. at 36 .

57. Id. at 37 .

58. 15 N.E.3d 595 (Ind. Ct. App. 2014).

59. Id. at 597-98.

60. Id. at 598 .

61. Id.

62. See id. at 598-99.

63. Id. at 599.

64. Id. at 599-601. 
meritorious claim or defense to the claim. ${ }^{65}$ The Court of Appeals determined that property owner's reliance on a conversation with an unknown representative from lender's foreclosure counsel's office was reasonable grounds for his failure to file an answer to the lender's foreclosure complaint. ${ }^{66}$ As to the meritorious defense prong of the test, the Court of Appeals observed that "Trial Rule 60(B) by its terms requires only an allegation of a meritorious defense," which shows that "if the case was retried on its merits, a different result would be reached." Although property owner did not challenge the validity of the debt, mortgage or failure to pay the note, the Court of Appeals found that property owner had pled facts sufficient to support a defense of estoppel and contractual sabotage based upon the conversation with the lender's foreclosure counsel's representative, and the lender's failure to respond to multiple short sale offers. ${ }^{68}$ Thus, the Court of Appeals reversed the trial court's order denying the property owner's motion to set aside default judgment. ${ }^{69}$

\section{E. Interpretation of Promissory Note}

In John M. Abbott, LLC v. Lake City Bank, ${ }^{70}$ the Court of Appeals considered whether the terms of a promissory note were intrinsically ambiguous. ${ }^{71}$ John M. Abbott, LLC ("Abbott") acquired a retail hardware business in 2006 and financed the acquisition with a loan obtained from lender. ${ }^{72}$ Abbott executed a promissory note (the "Note") in the original principal amount of $\$ 150,000$ with a variable interest rate based on a $3.4 \%$ spread over Five Year Treasury Bills. ${ }^{73}$ The Note indicated the initial rate would be $8.310 \%$ per annum, based upon the current index of the Five Year Treasury Bill $(4.910 \%){ }^{74}$ The Note limited interest rate changes to no more than once every five years. ${ }^{75}$ The Note also provided that the "annual interest rate for this Note is computed on a $365 / 360$ basis; that is, by applying the ratio of the annual interest rate over a year of 360 days, multiplied by the outstanding principal balance, multiplied by the actual number of days the principal balance is outstanding." "76 The Note also contained an acknowledgment that Abbott read and understood the Note terms prior to signing. ${ }^{77}$ In June 2009, lender filed a commercial foreclosure action against

65. Id.

66. Id. at 600-01.

67. Id. at 601 .

68. Id. at 602 .

69. Id.

70. 14 N.E.3d 53 (Ind. Ct. App. 2014).

71. Id. at 57 .

72. Id. at 54 .

73. Id. at 55.

74. Id.

75. Id.

76. Id.

77. Id. 
certain borrowers, including Abbott. ${ }^{78}$ In response to the foreclosure actions some of the borrowers, including Abbott, filed a counterclaim seeking certification as a class and claimed that lender breached the terms of the Note pertaining to the interest rate. ${ }^{79}$ The trial court conditionally certified and stayed the class and later granted a motion to substitute Abbott as class representative. ${ }^{80}$ Abbott claimed that lender exceeded the agreed-upon initial interest rate stated in the Note by applying the $365 / 360$ ratio to determine accrued interest ${ }^{81}$ Lender filed a motion for summary judgment that the trial court granted. ${ }^{82}$ Abbott appealed. ${ }^{83}$

The Court of Appeals upheld the trial court's decision. ${ }^{84}$ The Court of Appeals observed that the $365 / 360$ method has consistently withstood legal challenges based upon ambiguity in the federal courts and in other jurisdictions. ${ }^{85}$ The Court of Appeals also noted that language used in the Note to explain the mathematical application of the 365/360 ratio to determine the accrued interest negates any confusion that would have otherwise been created if the Note had only mistakenly stated the ratio is to be applied to determine the interest rate. ${ }^{86}$ The Court of Appeals stated that the Note's application of the 365/360 method to calculate the interest rate "is an imprecision, but not so confusing that a reasonable person would think that the rate set by the Note would be calculated using something other than the 365/360 method," and found that "[i]t is clear that the term being defined is not the annual interest rate but rather the method of computing regular interest payments." $" 87$ Accordingly, the Court of Appeals found the Note was not ambiguous as a matter of law. ${ }^{88}$

\section{Property Taxes AND Tax Sales}

During the survey period, the Tax Court and the Court of Appeals published several opinions regarding the assessment of real property taxes and the applicability of certain real property tax exemptions to specific circumstances.

\section{A. Homestead Deduction}

In Kellam v. Fountain County Assessor, ${ }^{89}$ the Tax Court considered the proper standard for determining "an individual's principal place of residence" for

78. $I d$.
79. $I d$.
80. Id.
81. Id.
82. Id.
83. Id.
84. Id. at 58.
85. Id. at 57.
86. Id. at 58.
87. Id.
88. Id.
89. 999 N.E.2d 120 (Ind. T.C. 2013). 
purposes of a taxpayer's eligibility for a homestead property tax deduction..$^{90}$ Kellam arose from the application of Kellam and Myers, an unmarried couple, for mortgage and homestead deductions on co-owned property in Fountain County, Indiana (the "Fountain Property"). ${ }^{91}$ Kellam received a homestead deduction on the Fountain Property for 2009 and his March 2011 property tax statement for the Fountain Property reflected a homestead deduction for $2010 .{ }^{92}$ In March 2011, Kellam received a notice from the Fountain County Treasurer stating that the county assessor needed a Correction of Error document filled out for the Fountain Property. The notice also included an updated tax statement that did not include a homestead deduction on the Fountain Property for $2010 .{ }^{93}$ The Fountain County Assessor explained to Kellam that the homestead deduction had been removed from the Fountain Property because Kellam still had a 2010 homestead deduction on property he owned in Wells County (the "Wells Property") and it had been determined through utility usage that the Fountain Property was not Kellam's principal place of residence. ${ }^{44}$ Kellam explained that he was staying elsewhere while the Fountain Property underwent renovations. ${ }^{95}$

In reply, the Fountain County Assessor told Kellam that if the homestead deduction were removed on the Wells Property, the homestead deduction could then be reinstated on the Fountain Property. ${ }^{96}$ Kellam sent in the proper paperwork to demonstrate that the homestead deduction had been removed from the Wells Property; yet, the Fountain County Assessor still denied his reinstatement request, because Myers also had a 2010 homestead deduction on property she owned in Grant County (the "Grant Property"). ${ }^{97}$ Kellam filed a Petition for Correction of Error with the Fountain County Property Tax Assessment Board, and it was denied. ${ }^{98}$ The Indiana Board of Tax Review (the "Indiana Board") denied Kellam's petition on appeal based on the fact that an individual may only have one homestead deduction per year, and both Kellam and Myers had homestead deductions on the Wells Property and the Grant Property at the time they filed the homestead deduction application with the Fountain County Auditor. ${ }^{99}$ Kellam appealed to the Tax Court. ${ }^{100}$

The Tax Court concluded the Indiana Board's determination was not supported by substantial or reliable evidence. ${ }^{101}$ Before reaching its decision, the Tax Court rejected Kellam's argument that Kellam and Myers were entitled to
90. Id. at 122 .
91. Id. at 121 .
92. Id.
93. Id.
94. Id.
95. Id.
96. Id.
97. Id.
98. Id.
99. Id. at 122-23.
100. Id. at 122 .
101. Id. at 124 . 
jointly file for a homestead deduction as such a deduction is only available for married couples. ${ }^{102}$ The Tax Court also concluded Myers was not eligible for a homestead deduction on the Fountain Property, because she received a homestead deduction on the Grant Property. ${ }^{103}$ As for Kellam's petition, the Tax Court held Kellam had submitted sufficient evidence that he was no longer receiving a homestead deduction with respect to the Wells Property and had paid the subsequent property taxes due on that property. ${ }^{104}$ The Tax Court also rejected the Indiana Board's conclusion that the Fountain Property was not Kellam's principal place of residence because "Kellam was not residing there," concluding that the proper standard to determine residency "depends on the 'intention' to return to the property after an absence, not continuous physical presence at the property." 105 In addition to testifying that he was not physically residing at the Fountain Property, Kellam testified he was using the Fountain Property as his address for voter registration, driver's license and bank statements. ${ }^{106}$ Based upon this evidence, the Tax Court reversed the Indiana Board's decision. ${ }^{107}$

\section{B. Probative Evidence of Property Value}

In Grabbe v. Carroll County Assessor, ${ }^{108}$ the Tax Court considered the admissibility of certain types of evidence offered by a property owner to contest the assessed value of his real property. ${ }^{109}$ Grabbe arose from a property owner's appeal of the assessed value of two adjoining agricultural parcels (the "Property"). ${ }^{110}$ For the 2009 tax year, the Carrol County Assessor valued the Property at $\$ 274,500 .{ }^{111}$ The property owner appealed the assessment to the Carrol County Property Tax Assessment Board of Appeals, then to the Indiana Board offering "four self-prepared analyses to demonstrate that the assessed value of the subject property should only be $\$ 218,262 . " 112$ The Indiana Board found the property owner's analyses lacked probative value, upholding the Carroll County Assessor's assessment. ${ }^{113}$ The property owner appealed to the Tax Court. ${ }^{14}$

102. Id. at 123 .

103. Id.

104. Id.

105. Id.

106. Id.

107. $I d$.

108. 1 N.E.3d 226 (Ind. T.C. 2013).

109. $I d$.

110. Id. at 227 .

111. Id.

112. Id. The four analyses were based on four separate appraisal methods: allocation, cost, income, and market data.

113. Id.

114. Id. 
The Tax Court upheld the Indiana Board's determination that the property owner's analyses lacked probative value. ${ }^{115}$ Before considering the property owner's offered analyses, the Tax Court noted real property in Indiana is assessed "on the basis of its market value-in-use: the value 'of a property for its current use, as reflected by the utility received by the owner or a similar user, from the property." 116 "To determine a property's market value-in-use, assessing officials refer to a series of guidelines that explain the valuation process for both land and improvements." 117 The Tax Court further noted that assessments conducted in accordance with these guidelines are presumed accurate; however, a property owner may rebut the "presumption with evidence that indicates that the assessment does not accurately reflect the property's market value-in-use." 118 Probative evidence includes "actual construction costs, sales information regarding the subject or comparable properties, appraisals that are relevant to the market value-in-use of the property, and any other information complied in accordance with generally accepted appraisal principles." 119 Additionally, the Tax Court noted the property owner must show that its "suggested value accurately reflects the property's true market value-in-use (and, consequentially, that the assessor's assessed value does not)." 120

The Tax Court considered whether the property owners' four self-prepared analyses were probative evidence as to the Property's true market value-in-use. ${ }^{121}$ As to the property owner's allocation approach analysis, the Tax Court concluded the property owner actually applied two different appraisal methods - the allocation and abstraction methods-without providing any evidence of whether the use of these methods conformed with any accepted appraisal principles, a necessary requirement in order to rebut the presumption of accuracy given to assessments calculated using the Indiana assessment guidelines. ${ }^{122}$ As to the property owner's cost approach analysis (which "estimates the value of the land as if vacant and then adds the depreciated cost of the improvements as if new to arrive at a total estimate of value" ${ }^{123}$ ) the Tax Court found that analysis lacked probative value because Owner "failed to provide any objective evidence other than his own conclusory assumptions." 124 The Tax Court also concluded that property owner's income approach lacked probative value because property owner failed to provide any support for why the

115. Id. at 232-33.

116. Id a 227 (quoting 2002 Real Property Assessment MANuAl (2004 Reprint) (incorporated by reference at 50 IND. ADMIN. CODE 2.3-1-2, at 2 (2002 Supp.))).

117. Id. at 227-28 (citing REAL PROPERTY ASSESSMENT GuIDELINES FOR 2002-VERSION A (incorporated by reference at 50 IND. ADMIN. CODE 2.3-1-2, at Bks. 1 and 2 (2002))).

118. $I d$. at 228 .

119. Id. (citation omitted).

120. Id. (citing Eckerling v. Wayne Twp. Assessor, 841 N.E.2d 674, 678 (Ind. T.C. 2006)).

121. Id. at 228-32.

122. Id. at $228-29$.

123. Id. at 230 .

124. Id. at 229-30. 
deduction of property taxes as an expense was correct under generally accepted appraisal standards or why application of a twenty percent capitalization rate was appropriate. ${ }^{125}$ Lastly, the Tax Court determined that the property owner's market data approach lacked probative value because the property owner failed to submit any evidence to explain how he calculated the valuation of comparable properties and structures. ${ }^{126}$ The Tax Court affirmed the Indiana Board's final determination upholding the original $\$ 274,500$ assessment as the property owner had offered no probative evidence that the original assessment was wrong. ${ }^{27}$

\section{Indiana Tax Court Rule 3 Objections}

In Jones v. Jefferson County Assessor, ${ }^{128}$ the Tax Court considered whether an assessor's failure to object to a property owner's failure to file a request for a copy of an administrative record pursuant to Indiana Tax Court Rule 3 should bar a subsequent motion to dismiss filed by an assessor. ${ }^{129}$ Jones arose from property owners' appeal of their residential real property assessments for the 2008 and 2009 tax years to the Indiana Board. ${ }^{130}$ After the Indiana Board issued a final determination upholding the original assessment, the property owners filed an appeal with the Tax Court challenging the decision. ${ }^{131}$ The Jefferson County Assessor's (the "Assessor") attorney filed his appearance and answer, and the Tax Court held a telephonic case management conference and ordered the parties to submit their briefs on the merits of the case. ${ }^{132}$ Property owners timely filed their initial brief, and the Assessor filed a motion to dismiss along with a response brief. ${ }^{133}$ However, instead of addressing the merits of the case, the Assessor's brief argued that the motion to dismiss should be granted, because property owners did not timely request the Indiana Board to prepare a certified copy of its administrative record as required under Indiana Tax Court Rule 3. ${ }^{134}$

The Tax Court held that the Assessor waived its objection to property owners' failure to timely request the administrative record. ${ }^{135}$ In this instance, property owners failed to timely request that the Indiana Board prepare a certified copy of the agency record by mid-September as required under Indiana Tax Court Rule 3. ${ }^{136}$ The Tax Court noted that "[t]hrough a series of cases, the Indiana Supreme Court has held that a failure to timely file the administrative

125. Id. at 230-31.

126. Id. at 231-32.

127. Id. at $227,232-33$.

128. 6 N.E.3d 1048 (Ind. T.C. 2014).

129. Id. at 1048 .

130. Id.

131. Id.

132. Id.

133. Id. at 1049.

134. Id.

135. Id. at 1050.

136. Id. 
record pursuant to Indiana Tax Court Rule 3 is the type of legal error or procedural defect which, if not objected to at the appropriate time, is waived." ${ }^{137}$ Since the Assessor waited until mid-December to raise an objection to this procedural defect and had numerous communications with the Tax Court following the mid-September deadline, the Tax Court found that the Assessor waived its objection to the timeliness of property owners' administrative record request. ${ }^{138}$

\section{Challenging an Assessment Based Upon Lack of Uniformity and Equality}

In Thorsness v. Porter County Assessor, ${ }^{139}$ the Tax Court considered the burden of proof and sufficiency of evidence required for a property owner's appeal of a property assessment based upon a lack of uniformity. ${ }^{140}$ Thorsness arose out of a property owner's challenge to the March 1, 2007 assessment of his residential property for $\$ 1,647,800$, even though property owner had purchased the residential property for $\$ 1,650,000$ on January $31,2007 .{ }^{141}$ Property owner appealed this assessment to the county property tax assessment board on the basis that the assessment did not comply with the "uniform and equal" mandate of Indiana's constitution, which appeal was denied. ${ }^{142}$ Before the Indiana Board, the property owner argued that his property was assessed at $99.9 \%$ of its sale price while six other residential properties in the same area had been assessed at an average of $79.5 \%$ of their recent sales prices. ${ }^{143}$ In support of his argument, the property owner submitted a one-page spreadsheet that included the addresses of the six other properties, the sale dates and assessment values for each property, and the ratio of each property's sale price compared to its tax assessment value. ${ }^{144}$ The property owner requested that the Indiana Board reduce his tax assessment to $\$ 1,311,750$ (i.e., $79.5 \%$ of the sale price). ${ }^{145}$ The Indiana Board upheld the assessment, concluding the property owner's evidence lacked the appropriate statistical comparisons, did not include reliable sample properties, and failed to conform with professionally accepted standards. ${ }^{146}$ The property owner appealed to the Tax Court. ${ }^{147}$

The Tax Court affirmed the final ruling of the Indiana Board. ${ }^{148}$ On appeal, the property owner alleged two errors by the Indiana Board: its failure to

137. $I d$.

138. $I d$.

139. 3 N.E.3d 49 (Ind. T.C. 2014).

140. Id. at 52 .

141. Id. at 50 .

142. Id.

143. $I d$.

144. $I d$.

145. Id.

146. Id.

147. Id.

148. Id. at 54 . 
determine that the county assessor bore the burden of proof at the initial administrative hearing and its finding that the property owner's "evidence was not probative in demonstrating that the Assessor's assessment lacked uniformity." 149 Before analyzing property owner's arguments, the Tax Court noted that the Indiana Constitution "does not guarantee a taxpayer the personal right to 'absolute and precise exactitude as to the uniformity and equality of each individual assessment." "150 The Tax Court also noted that one established method of measuring uniformity and equality of property assessments is through an assessment ratio study. ${ }^{151}$ This method "compare[s] the assessed values of properties with an assessing jurisdiction with objectively verifiable data, such as sales prices or market value-in-use appraisals." ${ }^{152}$

As to who bore the burden of proof, the Tax Court acknowledged that Indiana Code section 6-1.1-15-1(p) provided that if the assessment for which a notice of review is filed increased the assessed value of property by more than five percent over the immediately preceding year, the assessor had the burden of proving that the assessment is correct. ${ }^{153}$ In the instant case, however, the Tax Court observed that the property owner did not claim that his property's assessment failed to reflect its market value-in-use - a claim for which the burden-shifting rule of Indiana Code section 6-1.1-15-1(p) would apply-but instead claimed that his otherwise correct assessment should be reduced under a "uniformity and equality claim," for which the burden-shifting rule of Indiana Code section 6-1.1-15-1(p) does not apply. ${ }^{154}$

As to the probative value of the property owner's evidence, the Tax Court concluded that the property owner's evidence failed to include an assessment ratio study that was both correctly stratified and statistically analyzed as required by the Department of Local Government Finance's administrative regulations. ${ }^{155}$ As a result, the Tax Court concluded that the Indiana Board did not err in finding the property owner failed to present probative evidence to demonstrate that the assessor's assessment lacked uniformity. ${ }^{156}$

149. Id. at 52 .

150. Id. at 51-52 (quoting State Bd. of Tax Comm'rs v. Town of St. John, 702 N.E.2d 1034, 1040 (Ind. 1998)).

151. Id. at 51 .

152. Id. (alteration in original) (quoting Westfield Golf Practice Ctr., LLC v. Washington Twp. Assessor, 859 N.E.2d 396, 399 n.3 (Ind. T.C. 2007)).

153. Id. at 52 (quoting IND. CODE $\S 6-1.1-15-1(\mathrm{p})$ (2009) (repealed 2011)).

154. Id. at 53. The Tax Court further characterized property owner's claim as not one of correctness but rather incorrectness in relation to other assessed value without regard to the market value-in-use of his property.

155. Id. at 53-54; see 50 IND. ADMIN. CoDE 14-1-1, 14-2-1 (2007).

156. Id. at 54 . 


\section{E. Fraternal Beneficiary Association and Charitable Purpose Property Tax Exemptions}

In Fraternal Order of Eagles No. 3988, Inc. v. Morgan County Property Tax Assessment Board of Appeals, ${ }^{157}$ the Tax Court considered the standard a property owner must meet in order to qualify for the fraternal beneficiary association and charitable purpose property tax exemptions. ${ }^{158}$ Fraternal Order of Eagles arose from property owner's application for a property tax exemption based on either "a fraternal beneficiary association exemption or a charitable purposes exemption for the 2006 tax year" on 2.23 acres of land with a 10,500 square foot lodge the property owner used "to raise funds for charitable organizations, to collect donations for needy families, and to host private events for its members." 159 The property owner would also occasionally allow other charitable organizations to host events at the lodge without charging a fee. ${ }^{160}$ The Morgan County Property Tax Assessment Board of Appeals denied both exemption requests. ${ }^{161}$

The property owner appealed to the Indiana Board. ${ }^{162}$ At its hearing, the property owner submitted evidence consisting of "its charitable donations from 2003 to 2006, its monthly profit and loss statements for 2005, several affidavits, and a Usage Study" to support that it used its property for fraternal and charitable purposes. ${ }^{163}$ The Indiana Board denied the property owner's request for the exemptions, and the property owner appealed to the Tax Court. ${ }^{164}$

The Tax Court upheld the Indiana Board's determination that the property owner did not qualify for the fraternal beneficiary association exemption. ${ }^{165}$ The Tax Court concluded that the Indiana Board correctly applied the standard established by the Court of Appeals in another context, ${ }^{166}$ rather than the standard contained in a 1944 Attorney General Opinion on which the property owner relied. ${ }^{167}$ Consequently, the Indiana Board's determination on this issue was not

157. 5 N.E.3d 1195 (Ind. T.C. 2014).

158. Id. at 1197 .

159. Id. at 1198 .

160. Id.

161. Id.

162. Id.

163. Id. (footnotes omitted).

164. Id.

165. Id. at 1201 .

166. Id. at 1199-200; see State Bd. of Tax Comm'rs v. Fort Wayne Sport Club, Inc., 258 N.E.2d 874, 880 (Ind. Ct. App. 1970) (“The term 'fraternal benefit society' or 'fraternal beneficiary association' shall mean any corporation, society, order or voluntary association, without capital stock, organized and carried on solely for the mutual benefit of its members and their beneficiaries, and not for profit and having a lodge system and representative form of government, and which shall make provision for the payment of [death] benefits in accordance with this act.") (alteration in original).

167. Id. 
contrary to law.

The Tax Court further upheld the Indiana Board's determination that the property owner did not present a prima facie case that it was a fraternal beneficiary association under the applicable Court of Appeals standard, "explaining that to make [such a] case [the] taxpayer must walk the Indiana Board through every element of its analysis rather than assuming that the evidence speaks for itself." 168 The Tax Court agreed with the Indiana Board that the property owner's other evidence was conclusory and failed to demonstrate that it met the six requirements of a "fraternal beneficiary association" under Indiana Code section 27-11-1-1, such as being governed by a representative system. ${ }^{169}$ The Tax Court also found the fact that the property owner was recognized as a "fraternal society" under federal law did not establish that it was a "fraternal beneficiary association" under Indiana law. ${ }^{170}$

The Tax Court upheld the Indiana Board's determination that the property owner was not entitled to a charitable purposes exemption, disagreeing with the property owner's assertion that using property for fraternal purposes was synonymous with "using property for charitable purposes because fraternal organizations collectively seek to promote the general welfare of their members and society in general." " usage study failed to provide information about the amount of time dedicated to charitable (exempt) purposes rather than social (non-exempt) purposes and also failed to provide proof that its activities were in fact charitable. ${ }^{172}$

\section{F. Charitable Purpose Property Tax Exemption}

In Hamilton County Assessor v. SPD Realty, $L L C,{ }^{173}$ the Tax Court again considered the application of the charitable purpose property tax exemption to a particular set of facts. ${ }^{174}$ Hamilton County Assessor arose from a group of people's ("Founders") creation of a public benefit corporation ("Tenant Corporation") which, according to Tenant Corporation's Articles of Incorporation, was formed for the "charitable purpose of procuring tissue donors, performing tissue donor recoveries and providing related donor services." ${ }^{175}$ Founders had difficulty renting a suitable space for their operations so they purchased a property (the "Property") through a related limited liability company ("Landlord Company") and leased approximately half of the building on the

168. Id. at 2000 (explaining the holding of Long v. Wayne Twp. Assessor, 821 N.E.2d 466, 471 (Ind. T.C. 2005)).

169. Id. at 1201.

170. Id.

171. Id. at 1202 .

172. Id.

173. 9 N.E.3d 773 (Ind. T.C. 2014).

174. Id. at 774 .

175. Id. 
Property to Tenant Corporation. ${ }^{176}$ Pursuant to the terms of the lease created between the parties, Tenant Corporation "would pay an annual base rent equivalent to [Landlord Company's] entire mortgage, all real and personal property taxes, and all build-out and operating expenses." ${ }^{177}$ Landlord Company filed an application for a property tax exemption with respect to the Property with the Hamilton County Property Tax Assessment Board of Appeals, which denied the exemption. ${ }^{178}$ On Landlord Company's appeal, the Indiana Board granted the exemption. ${ }^{179}$ The Hamilton County Assessor (the "Assessor") appealed to the Tax Court.

The Tax Court concluded that the Indiana Board correctly granted the Landlord Company the exemption since there was substantial evidence the Property was occupied and used for a charitable purpose. ${ }^{180}$ The parties agreed that a property tax exemption is appropriate where property is owned, occupied and predominantly used for a charitable purpose, but the Assessor did not present any evidence that Tenant Corporation was not engaged in a charitable purpose, other than an argument in its opening statement that challenged the Landlord Company's evidence. ${ }^{181}$

The Tax Court also upheld the Indiana Board's determination that the Landlord Company primarily owned the property for a charitable purpose. ${ }^{182}$ The Tax Court observed that, when the ownership, occupancy, and use of a property is not unified in one entity, Indiana law requires all entities that own, occupy, and use the property to have their own charitable purpose. ${ }^{183}$ The evidence submitted indicated the Founders formed Landlord Company for the sole purpose of acquiring and renting the Property to Tenant Corporation in furtherance of its charitable tissue bank operations. ${ }^{184}$ The Tax Court also held the close relationship between the two entities supported the Indiana Board's finding that each had a similar charitable purpose. ${ }^{185}$ The Assessor argued that the fact that Tenant Corporation paid above-market rent demonstrated that Landlord Company had a profit motive similar to commercial landlords, rather than a charitable purpose. ${ }^{186}$ The Tax Court disagreed, noting that the amount of rent charged to Tenant Corporation was designed to cover just the mortgage costs and operations expenses, not to generate profits for Landlord Company. ${ }^{187}$ Since the totality of the evidence indicated Landlord Company owned the Property to

176. Id.

177. Id. at 774-75.

178. Id. at 775 .

179. Id.

180. Id.

181. Id. at 776

182. Id. at 778 .

183. Id. at 775 .

184. Id. at 777 .

185. Id.

186. Id.

187. Id. at 778 . 
support the Tenant Corporation's charitable purpose, the Tax Court concluded there was no reasonable basis for overturning the Indiana Board's grant of the exemption. ${ }^{188}$

Finally, the Tax Court upheld the Indiana Board's determination that the Property complied with the occupancy requirements of Indiana Code section 61.1-10-36.3(a), even though the occupancy period was only for four months of the tax year at issue. ${ }^{189}$

\section{G. Obsolescence and Over Assessment of Real Property}

In Idris v. Marion County Assessor, ${ }^{190}$ the Tax Court considered the standard a property owner must meet to prove that a property tax assessment should be reduced as a result of obsolescence and over-assessment. ${ }^{191}$ Idris arose from property owners' appeal of the assessed value of a condominium unit in a sixstory, mixed-use building in downtown Indianapolis, featuring two bars on the first three floors and residential condominiums on the second three floors. ${ }^{192}$ The property owners unsuccessfully appealed its assessed value to the Marion County Property Tax Assessment Board of Appeals. ${ }^{193}$ On appeal to the Indiana Board, the property owners argued the assessed value should be reduced from $\$ 395,900$ to $\$ 270,000$ due to excessive noise, odors, and persistent crime. ${ }^{194}$ The property owners also presented real estate listings and county tax reports for other condominium units in the building that were both smaller and larger than their unit. The Indiana Board declined to reduce the assessment in its final determination and the property owners appealed. ${ }^{195}$

The Tax Court concluded the Indiana Board was correct in denying property owner's appeal. As for the property owners' obsolescence argument, the Tax Court noted that obsolescence is a form of depreciation to "either the functional or economic loss of value to property, which is expressed as a percentage reduction to an improvement's replacement cost." 196 To establish a prima facie case for an obsolescence adjustment, a taxpayer must present probative evidence during the Indiana Board hearing that (1) identifies the factors that are causing the obsolescence, and (2) quantifies the amount of obsolescence in which the taxpayer believes he or she is entitled. ${ }^{197}$ Although the Tax Court expressed sympathy for the property owners' plight, it noted the Indiana Board's ruling

188. Id.

189. Id.

190. 12 N.E.3d 331 (Ind. T.C. 2014).

191. Id. at 332 .

192. $I d$.

193. Id. The property owners appealed pro se.

194. Id.

195. Id. at 332-33.

196. Id. at 334 (citing ReAl Property ASSESSMENT GUIDELINES FOR 2002-VERSION A (2002) (incorporated by reference at 50 IND. ADMIN. CODE 2.3-1-2 (2002 Supp.))).

197. Id. 
"reflect[s] some of the challenges taxpayers have in understanding the complexities of our property tax system." 198 The property owners' evidence of "odor problems, excessive noise, and crime issues" did not establish any of these criteria; thus, the Tax Court concluded the Indiana Board did not abuse its discretion in this regard. ${ }^{199}$

The Tax Court also concluded the property owners did not establish that the assessed value of the other units in the building required a reduction in the property owner's assessment. ${ }^{200}$ Indiana real property is assessed based on its market value-in-use: "the value of a property for its current use, as reflected by the utility received by the owner or a similar user, from the property." 201 A taxpayer may challenge a property assessment and establish the market value-inuse by presenting probative, market-based evidence (such as sales information for comparable properties) explaining the characteristics shared by properties comparable to the subject property that are relevant to the fair market value. ${ }^{202}$ While the property owners presented evidence as to comparable properties, specifically other units in their building, the Tax Court noted that they failed to describe their own property, or explain how differences between their property and the comparable properties affected the market value-in-use of their property. ${ }^{203}$ As no probative evidence was presented as to this issue, the Tax Court upheld the Indiana Board's determination. ${ }^{204}$

\section{H. Original Jurisdiction of Tax Court to Enjoin the Collection of Property Taxes}

In West Ohio II, LLC v. Marion County Assessor, ${ }^{205}$ the Tax Court examined its jurisdiction over a property owner's appeal to enjoin the collection of property taxes during the pendency of an appeal of assessed value. ${ }^{206}$ West Ohio II arose out of property owner's appeal of the assessed value of a multi-tenant office building located in Indianapolis. ${ }^{207}$ Almost one year later, when the Marion County Property Tax Assessment Board of Appeals had not yet scheduled a hearing on the appeal, property owner filed a petition with the Tax Court seeking to enjoin the collection of property taxes based on the valuation that the property owner was appealing. ${ }^{208}$

198. Id.

199. Id.

200. Id. at 335 .

201. Id. at 334 (quoting 2002 ReAl Property Assessment MANUAL (2004 Reprint) (incorporated by reference at 50 IND. AdMIN. CODE 2.3-1-2 (2002 Supp.))).

202. Id. (citing Long v. Wayne Twp. Assessor, 821 N.E.2d 466, 471 (Ind. T.C. 2005)).

203. Id. at 335 .

204. Id.

205. 9 N.E.3d 267 (Ind. T.C. 2014).

206. $I d$. at 268 .

207. Id.

208. Id. 
The Tax Court concluded it did not have subject matter jurisdiction to hear the property owner's request. ${ }^{209}$ "Subject matter jurisdiction can only be conferred upon a court by the Indiana Constitution or by statute." 210 Indiana Code section 33-26-3 confers jurisdiction to the Tax Court only over "original tax appeals," which is defined as a case that (1) arises under Indiana's tax laws, and (2) is an initial appeal of a final determination of either the Indiana Department of State Revenue or the Indiana Board. ${ }^{211}$ Indiana Code section 3326-6-2(a) provides that a taxpayer who wishes "to initiate an original tax appeal must file a petition in the tax court to set aside the final determination of the department of state revenue or the Indiana board of tax review." "212 Indiana Code section 33-26-6-2(b) states that "a taxpayer who wishes to enjoin the collection of a tax pending the original tax appeal must file a petition with the tax court to enjoin the collection of the tax." 213

Conceding that it had not received a final determination from the Indiana Board, the property owner asserted three arguments as to why the Tax Court had jurisdiction. ${ }^{214}$ First, the property owner asserted that the "will raise" requirement for appellate petitions under Indiana Code section 33-26-6-2(b) implicitly contemplates pre-final determination jurisdiction. ${ }^{215}$ The Tax Court rejected the property owner's argument, noting that the statutory language at issue as a whole presumes the Tax Court has jurisdiction before the appellate petition requirements are triggered. ${ }^{216}$ Second, the property owner asserted that the authority of the Tax Court to issue injunctive relief is similar to the power to issue preliminary injunctive relief; thus, conferring jurisdiction over pre-final determination requests for injunctive relief. ${ }^{217}$ The Tax Court rejected this argument on the basis that its injunctive powers are not triggered until it has original jurisdiction. ${ }^{218}$ Third, the property owner asserted that the Tax Court was bound through the principal of stare decisis to follow its rationale and holding in American Trucking Ass' $n$, Inc. v. Indiana. ${ }^{219}$ However, the Tax Court also declined to follow American Trucking Ass'n, holding that the case was not binding. ${ }^{220}$

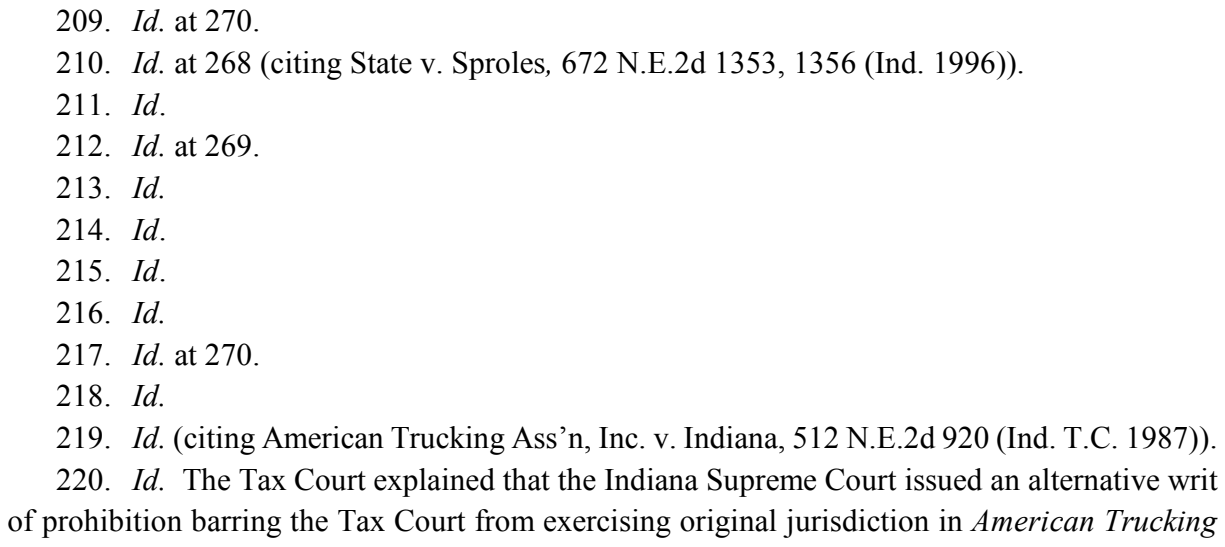




\section{Establishment of Neighborhood and Base Rate Determination for Assessment Purposes}

In McKeeman v. Carroll County Assessor, ${ }^{221}$ the Tax Court considered the proper standard to establish a property owner's "neighborhood" and base rate for purposes of assessed value of real estate. ${ }^{222}$ McKeeman arose out of a property owner's appeal of his 2006 tax year assessment based upon the failure to establish the property owner's "neighborhood" with the Steuben County Property Tax Assessment Board, which denied the property owner's appeal. ${ }^{223}$ The property owner appealed to the Indiana Board, which also upheld property owner's original assessment. ${ }^{224}$ Since the property owner was appealing a final determination of the Indiana Board, the Tax Court noted that the property owner had the burden of proof to demonstrate that the "Indiana Board's final determination is arbitrary, capricious, an abuse of discretion, not in accordance with the law, or unsupported by substantial evidence." ${ }^{225}$ On appeal to the Tax Court, the property owner unsuccessfully asserted three arguments as to the Indiana Board error. ${ }^{226}$

First, the property owner argued that the Indiana Board had improperly rejected his claim that the assessor did not correctly establish his neighborhood, even though some evidence was presented that certain properties in the neighborhood differed in size, usage, and access to roads. ${ }^{27}$ The Tax Court declined to find error, noting that the assessment guidelines permit a neighborhood to contain properties that vary with respect to road access, size and use types. ${ }^{228}$

Second, the property owner claimed that the properties used to establish his property's base rate were improper. ${ }^{229}$ The Tax Court rejected this argument, noting that the administrative record did not disclose what properties were utilized in developing the base rate, and the property owner failed to show the base rate was erroneous as applied to his property. ${ }^{230}$

Third, the Tax Court found that the property owner's sales comparison analysis lacked probative value because the analysis did not explain the circumstances surrounding the court-ordered sale of two comparison properties and sales details for two additional comparison properties. ${ }^{231}$ As a result, the analysis was not indicative of market value-in-use with respect to other offered

221. 10 N.E.3d 612 (Ind. T.C. 2014).

222. Id. at 613 .

223. Id.

224. Id.

225. Id. at 614 (citing IND. CoDE $\S 33-26-6-6(\mathrm{e})(1),(5)$ (2014)).

226. Id.

227. Id.

228. Id.

229. Id.

230. $I d$.

231. Id. at $616-17$. 
comparisons. $^{232}$

\section{J. Charitable Purpose Property Tax Exemption Burden of Proof}

In Housing Partnerships, Inc., v. Owens, ${ }^{233}$ the Tax Court considered a property owner's appeal of the denial of a charitable purpose property tax exemption for certain rental properties. ${ }^{234}$ Housing Partnerships involved a property owner that was incorporated in 1994 "to undertake, promote, develop and encourage any activity or means to ameliorate the housing needs of disadvantaged persons ... [and] to sponsor, support, and promote, and to undertake housing projects." 235 The property owner funded its housing projects from the sale and rental of its housing units, donations from individuals and businesses, and various public and private grants. ${ }^{236}$ In 2006, the property owner applied for a property tax exemption on each of its rental properties and its administrative office, claiming that the charitable purposes exemption set forth in Indiana Code section 6-1.1-10-16 applied to the properties. ${ }^{237}$ The Bartholomew County Property Tax Board of Appeals denied the application in March 2007. ${ }^{238}$ The property owner then appealed to the Indiana Board. ${ }^{239}$

At the Indiana Board hearing, the property owner provided testimony from its officers and a member of its board of directors indicating that the property owner had been recognized by the Internal Revenue Service as a 501(c)(3) organization, and describing the various housing and rehabilitation services that the property owner provided to the community. ${ }^{240}$ The Indiana Board denied the property owner's request for the exemption on the basis that the property owner had not demonstrated that the subject properties were owned, occupied and predominately used for a "charitable purpose," as the term is used in Indiana Code section 6-1.1-10-16. ${ }^{241}$ The property owner then appealed to the Tax Court. ${ }^{242}$

The Tax Court upheld the Indiana Board's determination that the property owner was not entitled to a charitable purposes exemption, concluding that the Indiana Board did not abuse its discretion in weighing the property owner's evidence with respect to the alleged charitable purpose of property owner's ownership, occupation, and use of the properties as low-income housing. ${ }^{243}$ To

232. $I d$.

233. 10 N.E.3d 1057 (Ind. T.C. 2014).

234. Id. at 1059 .

235. Id.

236. $I d$.

237. Id. at 1059-60.

238. Id.

239. Id. at 1060.

240. Id.

241. Id.

242. Id.

243. Id. at 1063 . 
constitute a charitable purpose, the property owner was required to demonstrate that (1) "its ownership, occupation and use of the subject properties as lowincome housing provided 'evidence of relief of human want . . . manifested by obviously charitable acts different from the everyday purposes and activities of man in general"" and (2) "through the accomplishment of those charitable acts, benefit inures to the public sufficient to justify the loss of tax revenue." 244

The property owner presented testimony that its housing efforts: were directed at distressed areas, relieved the government of its burden to revitalize those areas, provided below-market rental rates thereby relieving the government of its obligation to subsidize rents paid by tenants, and helped tenants become more financially self-sufficient. ${ }^{245}$ The Tax Court noted that the property owner's testimony was not supported by evidence in the administrative record showing that the government would have otherwise borne the burdens for the services provided by the property owner's activities and that the property owner's activities were not already subsidized by government services such as grants and financial subsidies. ${ }^{246}$ The Tax Court also upheld the Indiana Board's determination that the property owner was not entitled to a property tax exemption merely because the property owner received governmental grants, particularly since the property owner never explained whether the federal grants imposed any conditions on the receipt of the federal money. ${ }^{247}$ The Tax Court therefore found that the Indiana Board's determination was not "arbitrary, capricious, an abuse of discretion or contrary to law." 248

\section{K. Notice Requirements for Issuing a Tax Deed}

In Gupta v. Busan, ${ }^{249}$ the Court of Appeals considered the sufficiency of notice sent to a property owner to comply with statutory requirements for obtaining a tax deed. ${ }^{250}$ Gupta arose out of a purchaser's acquisition of the tax certificate for certain real property (the "Property") owned by a property owner at a tax sale. ${ }^{251}$ On February 24, 2009, the purchaser sent notice of the sale and redemption period, which was to expire on June 10,2009, to the property owner by certified and first class mail in compliance with the applicable statutory deadlines. ${ }^{252}$ The notices were not returned to purchaser. ${ }^{253}$ The purchaser also

244. Id. at 1061 (quoting Indianapolis Elks Bldg. Corp. v. State Bd. of Tax Comm'rs, 251 N.E.2d 673, 683 (Ind. Ct. App. 1969)).

245. Id. at 1061-62.

246. Id.

247. Id. at 1064 .

248. Id.

249. 5 N.E.3d 413 (Ind. Ct. App. 2014).

250. Id. at $414-15$.

251. Id. at 415 .

252. Id.

253. Id. 
posted notice of the sale at the Property. ${ }^{254}$ Following the expiration of the redemption period, the purchaser then mailed notice of his filing for petition for issuance of a tax deed to the property owner through certified and first class mail. ${ }^{255}$ Again, these notices were also not returned to the purchaser. ${ }^{256}$ The purchaser then subsequently petitioned for and was granted a tax deed for the Property. ${ }^{257}$ The property owner filed an action for quiet title in 2012, in which he claimed he never received any of the purchaser's notices and did not see the notice posted at the Property. ${ }^{258}$ At trial, the property owner argued that he did not receive notice as required by statute-specifically, that the purchaser failed to comply with the statutory certified mail requirements. ${ }^{259}$ The trial court granted summary judgment in the property owner's favor and denied the purchaser's cross-motion for summary judgment. ${ }^{260}$ Purchaser appealed. ${ }^{261}$

In considering purchaser's appeal, the Court of Appeals first noted that typically a tax deed is incontestable except by an appeal or a Trial Rule 60(B) motion filed within sixty days of the issuance of the deed, with the only exception being a constitutional challenge to the inadequacy of the notice. ${ }^{262}$ Despite the procedural irregularity, the Court of Appeals examined the purchaser's notices under Indiana's statutory notice requirements. ${ }^{263}$ In this instance, the purchaser had introduced certified mail receipts, postmarked by the post office as evidence that he sent the notices to property owner by certified mail; thus complying with the plain language of the statutory notice provision. ${ }^{264}$ The Court of Appeals declined to imply the term "certified mail" included the additional and distinct requirement the notice be sent "return receipt requested," overruling the trial court's grant of summary judgment in favor of the property owner. ${ }^{265}$

\section{Notices Required in Connection with a Tax Sale}

In the case of In re 2011 Marion County Tax Sale v. Marion County

\footnotetext{
254. $I d$.

255. $I d$.

256. Id.

257. Id.

258. Id.

259. $I d$.

260. Id.

261. $I d$.
}

262. Id. The Court of Appeals further noted that if treated as a Trial Rule 60(B) motion the trial court would only be permitted to consider the overall reasonableness of the notice provided, not the statutory requirements. Under the Court of Appeals' analysis, the notice was constitutional but could not be used as a basis for the Court of Appeals' decision since purchaser did not raise the issue at the trial court level or on appeal.

263. Id.

264. Id. at 417 .

265. $I d$. 
Auditor, ${ }^{266}$ the Court of Appeals considered the nature and extent of the notices that are required in connection with a tax sale, including whether the owner of a building that encroaches onto parcels that are delinquent must also be given formal notices in connection with the tax sale of the parcels that are delinquent. ${ }^{267}$ Marion County Tax Sale arose from a property owner's ("Taxpayer") failure to pay property taxes with respect to three contiguous tax parcels located in Marion County (the "Delinquent Tax Parcels"). ${ }^{268}$ The mailing address for one of the Delinquent Tax Parcels was also the business address of Taxpayer and was listed with the Marion County Auditor (the "Auditor") as Taxpayer's address (the "Business Address"). ${ }^{269}$ The principal of Taxpayer lived on a parcel contiguous to one of the three Delinquent Tax Parcels, and the building located on that tax parcel encroached by a few feet onto one of the three Delinquent Tax Parcels. ${ }^{270}$

At three different times - prior to the tax sale of the Delinquent Tax Parcels, immediately after the tax sale of the Delinquent Tax Parcels, and after the applicable redemption period for the tax sale had expired and a request for a tax deed had been filed - the Auditor had sent the applicable notices specified under Indiana Code sections 6-1.1-24-4 and 6-1.1-25-4.5. ${ }^{271}$ Each of the notices was first sent via certified mail to the Business Address and, when the certified mail went unclaimed, via first class mail to the Business Address. ${ }^{272}$ The Auditor also sent notices as to the completion of the tax sale and the expiration of the redemption period via certified mail and then via first class mail to an attorney listed as the agent for service of process for Taxpayer (the "Attorney"), but whose registered office was not current in Taxpayer's files with the Indiana Secretary of State, and to Michael Smith ("Smith"), whose interest in the Delinquent Tax Parcels the Auditor identified from a title examination of the Delinquent Tax Parcels. ${ }^{273}$ After the Auditor's prior notices received no response, the Auditor sent notices of the request for a tax deed and thirty day objection period via first class mail to the occupants of each of the three Delinquent Tax Parcels, to Taxpayer at the Business Address, and to the Attorney. ${ }^{274}$ Taxpayer claimed to have never received any of the notices and to have first learned of the tax sale after one of the occupants of one of the Delinquent Tax Parcels brought the issue to Taxpayer's attention. ${ }^{275}$ Taxpayer's principal testified that Taxpayer had historically had problems with mail being

\footnotetext{
266. 14 N.E.3d 883 (Ind. Ct. App. 2014).

267. $I d$.

268. Id. at 885 .

269. Id.

270. $I d$.

271. Id. at $885-86$.

272. Id.

273. Id.

274. Id.

275. Id. at 887.
} 
correctly delivered to the Business Address. ${ }^{276}$ The Auditor's office had no record of any of the notices that were sent via first class mail being returned as undeliverable. ${ }^{277}$ Taxpayer filed an objection, asserting in its initial filing that the notices had not been reasonably calculated to inform Taxpayer of the impending sales, and Taxpayer further argued that notice delivered after the sale had occurred did not cure the alleged defects in due process. ${ }^{278}$ The trial court ruled against Taxpayer and ordered that tax deeds be issued. ${ }^{279}$ Taxpayer appealed. ${ }^{280}$

The Court of Appeals agreed with the trial court, holding that the Auditor's notices via certified mail and first class mail to the Business Address, the Attorney, the occupants of the Delinquent Tax Parcels, and Smith met due process requirements. ${ }^{281}$ The Court of Appeals stated that a property may be sold in connection with unpaid property taxes under the Due Process Clause of the United States Constitution only if the government provides the owner with notice and an opportunity to be heard. ${ }^{282}$ The Court of Appeals noted that the Due Process Clause does not require actual notice; rather, only notice that is reasonably calculated to inform the parties of the nature of the claim is required. ${ }^{283}$ The Court of Appeals held that the Due Process Clause is satisfied by mailing notices to all addresses of which the applicable county auditor is aware, to the property itself, and to any third parties identified in a title search, as had been done in the instant case. ${ }^{284}$ In reaching its conclusion, the Court of Appeals specifically rejected the argument that the Auditor should have searched for an updated address for the Attorney, stating that the Auditor was not required to perform an open-ended search of the public records in order to effect service. ${ }^{285}$ The Court of Appeals also held that the Auditor was not required to provide additional notice by reason of the fact that a building located primarily on another property encroaches onto one of the Delinquent Tax Parcels. ${ }^{286}$ In rejecting that argument, the Court of Appeals noted that the Auditor was not aware of the encroachment and rejected any argument that the Auditor should be required to give notice to the owner of a neighboring encroaching improvement. ${ }^{287}$

276. Id. at $887-88$.

277. Id. at 888 .

278. Id. at 886 .

279. Id. at 889 .

280. $I d$.

281. Id. at $890-91$.

282. Id. at 890 .

283. Id.

284. Id. at 890-91.

285. Id. at 891.

286. Id.

287. Id. 


\section{Determining Assessed Value}

In Indianapolis Racquet Club, Inc. v. Marion County Assessor, ${ }^{288}$ the Tax Court considered whether the submission as evidence of property assessments from properties used for a similar purpose but located in other townships rebut the presumption that an assessed value is accurate. ${ }^{289}$ Indianapolis Racquet Club arose from property owner's ownership and operation of a tennis club located in Washington Township in Marion County. ${ }^{290}$ Believing the assessed value for each of the parcels encompassing the tennis club (the "Parcels") was too high, the property owner filed a petition with the Marion County Property Tax Assessment Board of Appeals (the "County Board") to challenge the assessed valuation of the Parcels. ${ }^{291}$ Instead of submitting an appraisal of the Parcels to support the property owner's appeal, the property owner presented the assessed value of other tennis clubs located in other townships and counties in the Indianapolis area. ${ }^{292}$ The property owner conceded that the assessed value of the Parcels was in accordance with the applicable township land order. ${ }^{293}$ However, the property owner argued that the use of the rates from the township land order was inappropriate because (1) the use of the Parcels differed significantly from that of other properties in the area with which the Parcels had been grouped in the applicable land order and were the only property in the neighborhood with their zoning classification; (2) unlike other properties in the vicinity, the Parcels did not have direct access to major cross streets; and (3) the Parcels included the only tennis facility in an area with significant retail, restaurant and gas station uses. ${ }^{294}$ After the County Board rejected the property owner's arguments on the basis that the property owner had failed to establish a prima facie case that the Parcels were overvalued, the property owner appealed to the Indiana Board, which affirmed the County Board's ruling. ${ }^{295}$ The property owner appealed to the Tax Court. ${ }^{296}$

The Tax Court upheld the decision of the Indiana Board. ${ }^{297}$ The Tax Court began by noting that, under Indiana law, real property is assessed on the basis of the property's "market value-in-use." ${ }^{298}$ A county assessor determines the "market value-in-use" of land other than farmland by examining recent sales of similar properties in the same area to prepare "land orders" that establish a range of base values per square foot (referred to as "base rates") to be applied to each property whose use falls within the applicable category of uses in that land

288. 15 N.E.3d 150 (Ind. T.C. 2014).

289. Id.

290. Id. at 151.

291. Id. at 152.

292. Id. at 154 .

293. Id.

294. Id. at $153-54$.

295. Id. at 152 .

296. Id.

297. Id. at 151.

298. Id. at 152 . 
order. ${ }^{299}$ A value as presented in a land order sometimes must be adjusted in order to arrive at a more accurate result. ${ }^{300}$ This is done by applying an "influence factor" to account for an increase or decrease in the land's value. ${ }^{301}$ An assessment made in accordance with a land order is presumed to be accurate. ${ }^{302}$ However, the presumption of accuracy can be rebutted by a taxpayer "with market-based evidence that indicates that the assessment does not accurately reflect the land's market value-in-use." 303

The Tax Court ruled that land assessments from land that was subject to different land orders are not probative evidence with respect to a property tax assessment appeal, without additional facts. ${ }^{304}$ In order for the assessed values of other tennis clubs to be probative, the property owner would need to present additional analysis as to how the factors applicable to the land subject to those other land orders also applied to the Parcels - something the property owner had failed to do. ${ }^{305}$ Also, in order to justify a decrease in value due to the use of the Parcels, the property owner would need to demonstrate how that use would negatively impact property value. ${ }^{306}$ Here, the property owner never attempted to do so. ${ }^{307}$ Finally, although property taxes under Article 10, Section 1 of the Indiana Constitution must be subject to a uniform and equal rate of taxation, merely showing that the assessed value of the Parcels was different from the assessed value of other tennis clubs did not establish a violation of this requirement. ${ }^{308}$ Instead, the taxpayer must establish that the assessed value did not bear the same relationship to market value as other properties in the same area, which the property owner failed to establish. ${ }^{309}$

\section{N. Establishing Prima Facie Case in Challenging an Assessment}

In Howard County Assessor v. Kokomo Mall, LLC, the Tax Court considered whether it could re-weigh evidence presented to the Indiana Board in connection with an assessment appeal and whether the presentation by a property owner of an appraisal report prepared in accordance with the Uniform Standards of Professional Appraisal Practice ("USPAP") established a prima facie case on behalf of the property owner as to the assessed value of the property in question. ${ }^{310}$

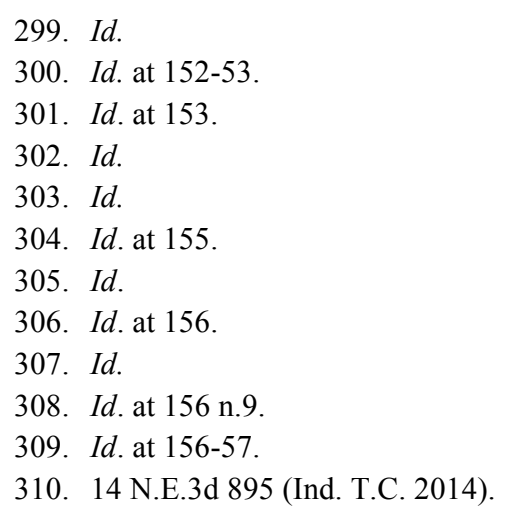


Howard County Assessor arose out of property owner's appeal of the assessed values of three different tax parcels in Howard County (the "Parcels") for three different tax years. ${ }^{311}$ After the property owner's appeal was initially denied by the Howard County Property Tax Assessment Board of Appeals, the property owner appealed to the Indiana Board. ${ }^{312}$ At the hearing before the Indiana Board, the property owner presented a summary appraisal report that had been prepared in accordance with USPAP standards. ${ }^{313}$ The Howard County Assessor (the "Assessor") argued that the appraisal had not been properly prepared in accordance with USPAP standards. ${ }^{314}$ The Indiana Board determined that the appraisal was probative of the value of the Parcels despite various defects in the appraisal and that the property owner had established a prima facie case that the assessed value was incorrect. ${ }^{315}$ The Indiana Board further found that the Assessor had not rebutted or impeached the evidence presented by the property owner, reducing the assessed value for all Parcels for the 2008 and 2009 tax years and reducing the appraised value of one Parcel for the 2007 tax year. ${ }^{316}$ The Assessor appealed to the Tax Court. ${ }^{317}$

The Tax Court noted that a party seeking to overturn a decision of the Indiana Board bears the burden of demonstrating that the decision is invalid by reason of being "arbitrary, capricious, an abuse of discretion, or otherwise not in accordance with the law . . . or unsupported by substantial or reliable evidence." 318 In applying this general rule, the Tax Court ruled that it can consider on appeal only issues of law and cannot attempt to gauge the probative value of evidence that was presented. ${ }^{319}$ Accordingly, the Tax Court did not consider the Assessor's arguments regarding the credibility of the property owner's evidence. ${ }^{320}$

The Tax Court also rejected the Assessor's proposal to reconsider the policy that a USPAP-prepared appraisal establishes a prima facie case for a property owner. ${ }^{321}$ Without specifically addressing whether such a policy exists, the Tax Court concluded the Indiana Board had not applied such a policy, but had rather reviewed the appraisal and found it probative as to the value of the Parcels. ${ }^{322}$ Accordingly, the property owner had rebutted the presumption that the county's assessed value was correct, and the Assessor had failed to present any evidence

311. Id. at 896-97.

312. Id.

313. Id. at 896 .

314. Id. at 896-97.

315. Id. at 897 .

316. $I d$.

317. Id.

318. Id. at 898 .

319. Id.

320. Id.

321. Id. at 899.

322. Id. 
to rebut or attach the findings of the appraisal. ${ }^{323}$ The Tax Court also concluded that a policy that required a county to rebut the conclusions of a USPAP-prepared appraisal would not be an undue burden on assessors. ${ }^{324}$ Instead, the Assessor could present other evidence, such as comparable sales, to rebut or impeach an appraisal presented by a taxpayer. ${ }^{325}$

\section{EASEMENTS, COVENANTS, AND TITLE ISSUES}

During the survey period, the Court of Appeals published several opinions in cases concerning easements, real property covenants, and other title issues.

\section{A. Public Standing Challenges to Indiana Code Section 20-23-6-9(d) Violations}

In Old Utica School Preservation, Inc. v. Utica Township, the Court of Appeals considered the applicability of the public standing doctrine to allegations of violation of Indiana Code section 20-23-6-9. ${ }^{326}$ Old Utica arose out of a school corporation's ("Corporation") transfer of a former elementary school ("School") to Utica Township ("Township") via quitclaim deed. ${ }^{327}$ In conformity with Indiana Code section 20-23-6-9, the deed included a restrictive covenant that stated the School could only be used "for park and recreation purposes." 328 The Township opened the School to the public but was soon unable to maintain its condition due to a lack of sufficient funds. ${ }^{329}$ On June 17, 2011, a non-profit company ("Company") leased the School from the Township and "invested approximately $\$ 300,000$ in renovations on the School." 330 The lease required the Company to allow the Township access to the gym and cafeteria for community events to take place in the School. ${ }^{331}$ The Corporation knew about the Company's use of the School but did not object or take any action to reclaim authority over the School. ${ }^{332}$ On October 25, 2012, several individuals who owned land adjacent to the School as well as a non-profit historical preservation society (collectively, "Citizens") filed a complaint seeking declaratory judgment and injunctive relief, asserting that the Company did not use the school solely for park and recreation purposes as required by Indiana law. ${ }^{333}$ The Company filed

323. Id.

324. Id.

325. $I d$.

326. Old Utica Sch. Pres., Inc. v. Utica Twp., 7 N.E.3d 327, 329-30 (Ind. Ct. App.), trans. denied, 16 N.E.3d 980 (Ind. 2014).

327. Id. at 329.

328. Id. (noting that at the time the property was transferred, the statutory provision at issue was codified at IND. CODE $§ 20-4-5-8$ (repealed 2005)).

329. Id.

330. $I d$.

331. Id.

332. Id.

333. Id. 
a motion for summary judgment on December 7, 2012, arguing that the Citizens lacked standing to bring their claim. ${ }^{34}$ The trial court held that the Citizens did not have standing, granted summary judgment in favor of the Township and dismissed the Citizens' complaint. ${ }^{335}$ The Citizens then filed a motion to correct error, which the trial court denied. ${ }^{336}$ The Citizens' appeal ensued..$^{337}$

The Court of Appeals concluded that the public standing doctrine conferred to Citizens the right to enforce the restrictive covenant in the School's deed to the Township. ${ }^{338}$ The Court of Appeals noted that, in general, "only those persons who have a personal stake in the outcome of the litigation and who show that they have suffered or were in immediate danger of suffering a direct injury as a result of the complained-of conduct will be found to have standing" to bring an action. ${ }^{339}$ One exception to this rule is the public standing doctrine, which "applies [both] in cases where public rather than private rights are at issue and in cases that involve the enforcement of a public rather than a private right."340 The Court of Appeals found that a public right was at issue: Since the School property was deeded to the Township, the statutory language in Indiana Code section 20-23-6-9(d) required that the School property be used for park and recreational purposes. ${ }^{341}$ Thus, the public had an interest in enforcing the use restrictions. ${ }^{342}$ The Court of Appeals further noted it was not considering whether the lease between the Township and the Company violated the restrictive covenant in the School deed or what a township should do when confronted with similar situations, where funds are not available to maintain property transferred via Indiana Code section 20-23-6-9. ${ }^{343}$

\section{B. Adverse Possession and Prescriptive Easements}

In Flick v. Reuter, the Court of Appeals considered whether (1) a property owner was liable to a prior owner of the property's aunt ("Possessor") for damages incurred when the property owner attempted to evict the Possessor from the property owner's property ("Property") without legal process and (2) Possessor had acquired fee title to or other legal right to remain on the Property through adverse possession. ${ }^{344}$ Landowners purchased the Property in 1982. ${ }^{345}$

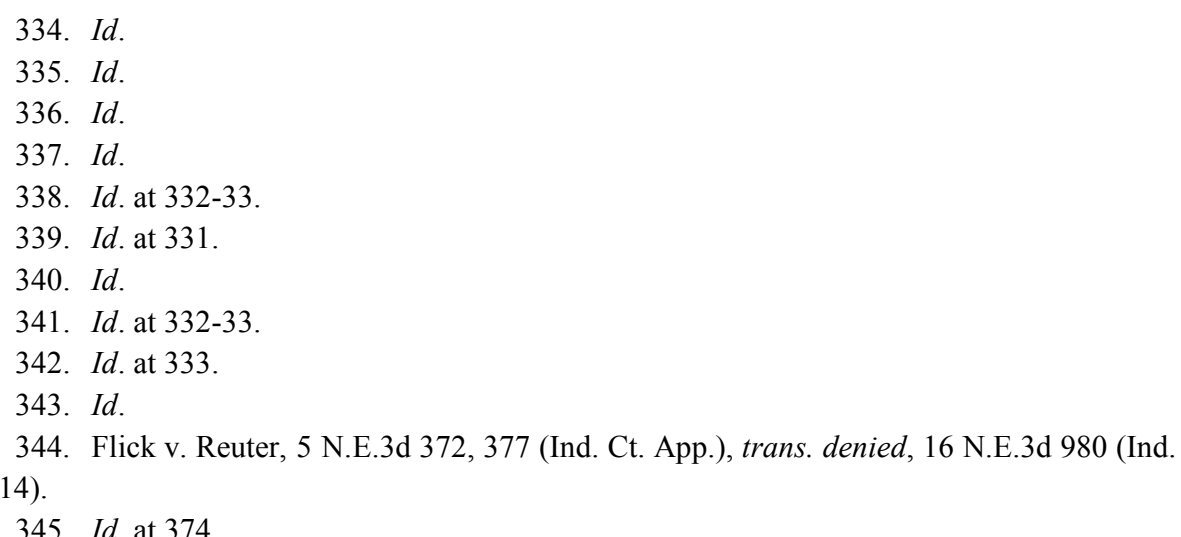

345. Id. at 374 . 
Five years later, the landowners allowed Possessor to live in a mobile home on 0.8 acres of the Property ("Disputed Property"). ${ }^{346}$ The Disputed Property was never deeded to Possessor. ${ }^{347}$ Possessor lived on the Disputed Property, tended the land, gardened, and had a septic system and water lines installed on the Disputed Property. ${ }^{348}$ When Possessor first moved to the Disputed Property, she received property tax statements and paid them, believing that they were for the Disputed Property. ${ }^{349}$ In 1988, landowners deeded 2.28 acres to their son, which included the Disputed Property. ${ }^{350}$ For the next two decades, Possessor continued to live on and maintain the Disputed Property without dispute. ${ }^{351}$

In 2010, a new property owner ("New Owner") purchased the 2.28 acres, which included the Disputed Property. ${ }^{352}$ New Owner surveyed the 2.28 acres, which revealed that Possessor's mobile home, yard, well, and part of her septic system were all located on the Property. ${ }^{353}$ New Owner offered to purchase Possessor's mobile home but Possessor declined the offer. ${ }^{354}$ Property owner then cut off the water supply to the mobile home and severed the lines that ran to Possessor's well. ${ }^{355}$ New Owner also filed a complaint against Possessor for trespass in the Lawrence County Circuit Court. ${ }^{356}$ Possessor then filed an answer and counterclaimed against New Owner for trespass, obtaining a default judgment against New Owner when he failed to timely respond. ${ }^{357}$ New Owner later had the default judgment set aside. ${ }^{358}$ In the meantime, New Owner entered onto Possessor's property and mowed over her plants and installed an electric fence around the perimeter of her mobile home, preventing her from entering into the mobile home temporarily. ${ }^{359}$ Possessor then filed a motion to amend her counterclaim, adding a request for attorney's fees and damages and summary judgment onto her complaint. ${ }^{360}$ New Owner also filed a motion for summary judgment. ${ }^{361}$ The trial court granted summary judgment in Possessor's favor, finding that Possessor had acquired title to the Disputed Property through adverse possession and through the establishment of a prescriptive easement. ${ }^{362}$ The trial

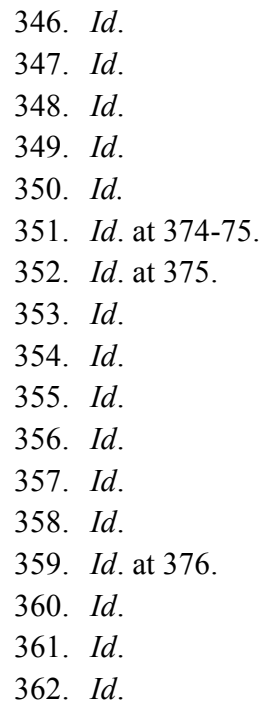


court also granted her motion to quiet title and ordered New Owner to pay $\$ 29,487.70$ in damages. ${ }^{363}$ New Owner appealed the trial court's rulings. ${ }^{364}$

The Court of Appeals upheld the trial court's award of $\$ 29,487.70$ in damages to Possessor, but overruled the trial court's grant of summary judgment in favor of Possessor on her adverse possession claim. ${ }^{365}$ With respect to Possessor's damages claim, the Court of Appeals noted that New Owner improperly resorted to self-help remedies by cutting the water lines, mowing down Possessor's plants, and installing an electric fence around Possessor's mobile home. ${ }^{366}$ In doing so, New Owner improperly committed trespass to chattel instead of using the available legal remedies: an action for ejectment or writ of assistance. ${ }^{367}$

With respect to Possessor's adverse possession claim, the Court of Appeals determined Indiana Code section 32-21-7-1 requires that an "adverse possessor pay and discharge: all taxes and special assessments that the adverse possessor ... reasonably believes in good faith to be due on the land" during the claimed period, in addition to establishing the elements of control, intent, notice, and duration for the statutory period of ten years. ${ }^{368}$ In this instance, the documents provided by Possessor showed that she only paid taxes on her mobile home from 2006 to 2010 and not the Disputed Property, and thus the trial court should have granted summary judgment in favor of New Owner. ${ }^{369}$

The Court of Appeals also held that the trial court improperly granted summary judgment in favor of Possessor on her prescriptive easement claim. ${ }^{370}$ Before analyzing Possessor's claim, the Court of Appeals noted that the "law disfavors prescriptive easements"; accordingly, the party claiming a prescriptive easement must meet stringent requirements. ${ }^{371}$ For a prescriptive easement to have been created, there must be evidence of "an actual, hostile, open, notorious, continuous, uninterrupted adverse use for twenty years under a claim of right." $" 372$ The Court of Appeals concluded that Possessor failed to meet the "adverse" element of a prescriptive easement claim because, as landowners allowed her to live on the Disputed Property, her use of the land was permissive and not adverse. ${ }^{373}$ Additionally, the Court of Appeals found that Possessor did not submit any evidence to show that she communicated, either explicitly or implicitly, to the previous landowners that she was staying on the property under

363. Id. at 377.

364. Id.

365. Id. at 378-81. The Court of Appeals also considered and upheld the trial court's decision to set aside Possessor's default judgment for property owner's failure to appear.

366. Id. at 378 .

367. Id.

368. Id. at 380 .

369. Id. at $380-81$.

370. Id. at 381 .

371. Id.

372. Id. at 382 .

373. Id. 
a claim of right. ${ }^{374}$

\section{Restrictive Covenants in Residential Declarations}

In Avon Trails Homeowner's Ass' $n$, Inc. v. Homeier, the Court of Appeals considered the interpretation of a restrictive covenant contained in a declaration of covenants for a residential subdivision. ${ }^{375}$ In Avon Trails, a homeowners' association ("Association") managed a subdivision ("Subdivision") that was governed by a Declaration of Covenants, Conditions, and Restrictions ("Declaration"). ${ }^{376}$ The Declaration contained a provision prohibiting the outdoor storage of semi-tractor trucks, trailers, boats, and similar items within the confines of the Subdivision. ${ }^{377}$ A homeowner in the Subdivision ("Owner") had a trailer parked on her lot within the Subdivision. ${ }^{378}$ On four different occasions, the Association sent a letter to Owner notifying her that she violated the restrictive covenant contained in the Declaration and requesting that she remove the trailer. ${ }^{379}$ Each time, Owner failed to remove the trailer. ${ }^{380}$ The Association sent the fourth letter through its counsel and specified that the trailer had to be moved by a certain date. ${ }^{381}$ When Owner failed to remove the trailer by the specified date, the Association filed a complaint and motion seeking a preliminary injunction. ${ }^{382}$

At the hearing, the trial court sua sponte raised the issue of whether the restrictive covenant contained in the Declaration even applied to lot owners within the Subdivision. ${ }^{383}$ The trial court ultimately denied the Association's request for a preliminary injunction, finding that the restrictive covenant did not apply to lot owners within the Subdivision. ${ }^{384}$ The Association then filed its notice of appeal on December 6, 2012. ${ }^{385}$ However, on April 30, 2013, the Association and Owner jointly filed a motion to vacate the trial court's order and to impose a permanent injunction on Owner. ${ }^{386}$ In the motion, Owner agreed that the restrictive covenant did apply to owners within the Subdivision and agreed to a permanent injunction preventing her from storing a trailer on her lot. ${ }^{387} \mathrm{On}$

374. Id.

375. Avon Trails Homeowners Ass'n, Inc. v. Homeier, 1 N.E.3d 731, 732-33 (Ind. Ct. App. 2013).

376. Id. at 733 .

377. Id.

378. Id.

379. Id.

380. Id.

381. Id.

382. Id.

383. Id. at 734 .

384. Id.

385. Id.

386. Id.

387. Id. 
May 1, 2013, the trial court denied the parties' joint motion and the parties appealed. ${ }^{388}$ On June 11, 2013, the Court of Appeals issued an order granting the parties' joint motion in part, dismissing the matter without prejudice, and remanding the case back to the trial court. ${ }^{389}$ On remand, the trial court reinstated its May 1, 2013, order denying the parties' joint motion. ${ }^{390}$ The Association's appeal followed. ${ }^{391}$

The Court of Appeals held that the restrictive covenant did apply to owners of lots within the Subdivision, finding that the language prohibiting the storage of trailers and other items within the Declaration was clearly intended to apply to lot owners within the subdivision. ${ }^{392}$ Therefore, the Court of Appeals determined that the trial court's order was clearly erroneous. ${ }^{393}$ As a result, the Court of Appeals reversed the trial court's determination and ordered the trial court to grant the parties' joint motion. ${ }^{394}$

\section{Shared Use/Maintenance Provisions in Deeds}

In Terry Weisheit Rental Properties, LLC v. David Grace, $L L C,{ }^{395}$ the Court of Appeals considered the meaning of shared use/maintenance language in a series of deeds. ${ }^{396}$ Terry Weisheit Rental arose from Terry Weisheit Rental Properties, LLC's ("Weisheit") and David Grace, LLC's ("Grace") ownership of subdivided parcels of real estate that had been under common ownership until $1981 .^{397}$ In 1981, the northern portion of the property was conveyed to Grace's predecessor in title in two lots, each improved with paved parking and drive areas with only one lot, Lot $21 \mathrm{a}$, providing access to public streets. ${ }^{398}$ The southern portion, comprised of three lots, was similarly improved with paved parking and driving areas and provided access to public streets via Lot $21 \mathrm{~b} .{ }^{399}$ The deed by which Weisheit took title to the northern lots (the "Weisheit Deed") included the following provision:

ALSO, the mutual use and maintenance of a drive whose centerline is 82 feet South of the Northwest corner of said Lot \#20, the mutual use and

388. Id. at $734-35$.

389. Id. at 735 .

390. Id.

391. Id.

392. Id. at 737.

393. Id. The trial court had concluded that the general prohibition against parking trailers was only applicable to the declarant, home builders and the Association because the Declaration permitted the same parties to park trailers in the event it was necessary to perform their respective responsibilities.

394. Id. at 738 .

395. 12 N.E.3d 930 (Ind. Ct. App. 2014).

396. Id. at 932 .

397. Id. at 933 .

398. Id.

399. Id. 
maintenance of the parking areas, and the equal sharing of expenses of maintaining the party wall comprising the southerly side of the structure located on above-described tract and the northerly side of the structure located on grantors' tract adjoining to the South of the above described tract. $^{400}$

The deed by which Grace took title ("Grace Deed") contained a virtually identical provision. ${ }^{401}$ Both properties were improved with commercial buildings that shared a party wall running east-west; Weisheit owned the southern portion and Grace the northern portion. ${ }^{402}$ Weisheit operated a construction business and leased space to other commercial tenants on its property. ${ }^{403}$ Grace leased its property to Dance Central Academy ("Dance Central"). ${ }^{404}$

Weisheit's business and that of Grace's predecessor-in-title required delivery by large trucks that had to cross Lot 21a (part of the Grace property), and trucks delivering to Grace's predecessor-in-title had to cross Lot $21 \mathrm{~b}$ (part of the TW property) in order to reach the appropriate loading dock. ${ }^{405}$ Customers and patrons of Grace's tenant, Dance Central, frequently used the paved parking and drive areas on both the Grace property and the Weisheit property. ${ }^{406}$ Weisheit objected, and at one point parked a box truck just south of the property line between Lots $21 \mathrm{a}$ and $21 \mathrm{~b}$, which caused problems for customers trying to park in front of Dance Central. ${ }^{407}$ Grace brought a quiet title action to establish its claim of an easement based on the Grace Deed. ${ }^{408}$ The trial court concluded that the deeds to the Grace property (i.e. the Grace Deed and that of Grace's predecessor-in-title) did not create an easement, but, rather, "a prescriptive easement existed as to all parties for the mutual use of [Lots] 21a and 21b." ${ }^{409}$ Weisheit appealed the finding of a prescriptive easement and Grace appealed the finding that the deed failed to create an express easement. ${ }^{410}$

The Court of Appeals concluded that the trial court erred in interpreting the Grace Deed and Weisheit Deed as both clearly included "language establishing mutual obligations for maintenance of those commonly-used parts of the parking and driving areas and the party wall." ${ }^{\text {111 }}$ The Court of Appeals concluded easements were not established because the provisions lacked a clear indication

\footnotetext{
400. $I d$.

401. $I d$.

402. Id.

403. Id.

404. Id. at $933-34$.

405. $I d$.

406. Id. at 934 .

407. Id.

408. Id.

409. Id.

410. Id.

411. Id. at 935.
} 
of the dominant and servient estates. ${ }^{412}$ Instead, the clear duties and rights established by the Grace Deed and Weisheit Deed created an affirmative covenant, which is an affirmative burden on each grantee to perform some act. ${ }^{413}$ Covenants may be personal or run with the land, depending on the intent of the parties to the covenant. ${ }^{414}$ A covenant will run with the land if: (1) the parties intend it to run with the land (which intent may be expressed in the covenant or inferred from the circumstances at the time the covenant was entered into), (2) the covenant touches and concerns the land (i.e., if the covenant is logically connected to the use and enjoyment of the property interest it binds), and (3) there is privity of estate between subsequent grantees of the original parties to the covenant. ${ }^{415}$ In this instance, the Court of Appeals concluded that the Grace Deed and Weisheit Deed created affirmative covenants that ran with the land and were binding upon successors-in-interest with respect to the mutual use and maintenance of the parking and driving areas and the party wall. ${ }^{416}$

\section{E. Tenancy by the Entireties and Rights of Survivorship}

In Powell v. Estate of Powell, ${ }^{417}$ the Court of Appeals considered the legal effect of a conveyance of real estate by the entirety to two or more individuals who are not husband and wife, an issue that was a matter of first impression in Indiana. ${ }^{418}$ Powell arose from a grantor's 1995 conveyance of certain property (the "Property") to his two sons, Kevin Powell ("Kevin") and Gary Powell ("Gary"). ${ }^{419}$ The deed vesting title in the name of the brothers stated as follows: "[T]his Indenture Witnesses that Lawrence H. Powell . . CONVEY and WARRANT [sic] to G. Kevin Powell ... and Gary Lee Powell ... , as tenants by the entireties ...., the following described real estate in Washington County, State of Indiana . . . ." ${ }^{420}$ Gary died in 2013 and was survived by Kevin. ${ }^{421}$

Following Gary's death, his estate (the "Estate") filed a complaint for declaratory judgment seeking a ruling that title to the Property was held by Kevin and Gary as tenants in common and not as joint tenants with rights of survivorship. ${ }^{422}$ Kevin filed a counterclaim asking for declaratory judgment that the deed created a joint tenancy with right of survivorship - meaning that upon the death of Gary, Kevin became the sole owner of the Property-rather than a

\footnotetext{
412. Id. at 936 .

413. Id. at 937 .

414. Id.

415. Id.

416. Id. at 938 .

417. 14 N.E.3d 46 (Ind. Ct. App. 2014).

418. Id. at 47.

419. Id. at 46-47.

420. Id. at 47 .

421. Id.

422. Id.
} 
tenancy in common. ${ }^{423}$ The trial court conducted a hearing and held the Property was intended to be held by the brothers as tenants in common. ${ }^{424}$ Kevin appealed. $^{425}$

The Court of Appeals overruled the trial court's interpretation of the deed. ${ }^{426}$ Because a tenancy by the entirety can only be held by a husband and wife, the Court of Appeals observed that the only two possibilities of ownership between Kevin and Gary were a tenancy in common or a joint tenancy with rights of survivorship. $^{427}$ The Court of Appeals agreed that the relevant statute for purposes of interpreting the deed was Indiana Code section 32-17-2-1(c), which provides:

Except as provided in subsection (b), a conveyance or devise of land or any interest in land made to two (2) or more persons creates an estate in common and not in joint tenancy unless:

(1) it is expressed in the conveyance or devise that the grantees or devisees hold the land or interest in land in joint tenancy and to the survivor of them; or

(2) the intent to create an estate in joint tenancy manifestly appears from the tenor of the instrument. ${ }^{428}$

Thus, the statutory presumption in Indiana is that concurrent owners of real estate are tenants in common, unless one of the two exceptions is applicable to the granting provision. ${ }^{429}$ In Powell, the first exception in subsection (c)(1) did not apply, as the deed did not specifically express a joint tenancy with rights of survivorship. ${ }^{430}$ As a result, the key question was whether the grantor expressed an intent to convey the Property to Kevin and Gary in joint tenancy. ${ }^{431}$ In answering this question, the Court of Appeals first noted that one of its rules of construction in interpreting a deed is to presume that the party or parties drafting it intended for every part of the deed to have some meaning. ${ }^{42}$ The Court of Appeals concluded the most notable aspect of tenancy by the entirety is that upon the death of one tenant, the surviving tenant takes possession of the whole- the right of survivorship. ${ }^{433}$ By specifying that Kevin and Gary would take the property "as tenants by the entireties," the Court of Appeals concluded that the grantor meant to convey the right of survivorship, and as a result, the Property

\footnotetext{
423. $I d$.

424. Id.

425. $I d$.

426. Id. at 48 .

427. $I d$.

428. Id.

429. Id. at 49 .

430. $I d$.

431. Id. at 49-50.

432. Id. at 50 .

433. Id.
} 
was to be held by Kevin and Gary as joint tenants with rights of survivorship. ${ }^{434}$

\section{Oil AND Gas Leases AND Mineral Rights}

During the survey period, the Court of Appeals published two opinions in cases concerning oil and gas lease and mineral rights issues.

\section{A. Royalty and Automatic Termination Provisions}

In L.C. Neely Drilling, Inc. v. Hoosier Energy Rural Electrical Cooperative, Inc., ${ }^{435}$ the Court of Appeals considered the interpretation of an advanced royalty clause in an oil and gas lease. ${ }^{436}$ L.C. Neely arose out of an oil and gas lease entered between a landowner ("Original Owner") and an oil company (the "Company") in 2003 (the "Original Lease"). ${ }^{437}$ The Original Lease required the Company to pay five dollars per acre as an advanced royalty per year if actual royalties on oil production had not been paid within thirty-six months of the commencement of the Original Lease term. ${ }^{438}$ The Original Lease further provided that Original Owner must demand payment of "any amount due" prior to terminating the Original Lease for failure to pay (the "Demand Clause"). ${ }^{439}$ In 2008, the Company and Original Owner entered into an amendment to the Original Lease (the "Lease Amendment") which provided that the lease would remain in effect for a period of five years from the original January 3, 2004, commencement date and continue "as long ... as gas is produced and sold from the Lands or from lands pooled therewith or advance royalties are paid." ${ }^{\prime 40}$ The Lease Amendment also included a clause providing that if no royalties were paid or accruing at the end of the thirty-six month period, the lease would continue to be "in force and effect from year to year . . . upon payment or tender to the Lessor of Advance Royalties . . . being made annually thereafter on or before the anniversary date of the expiration of said 36 month period" (the "Advance Royalties Clause"). ${ }^{41}$ The Demand Clause was not amended. ${ }^{442}$

By January 2012, no royalties had been paid, and a new landowner ("New Owner") had acquired fee simple title to the subject property. ${ }^{443}$ The Company failed to timely pay the 2012 advance royalties by the January 3, 2012, deadline but sent a check for advance royalties to New Owner on January 27, 2012. ${ }^{44}$ New Owner returned the check and notified the Company that the lease had

\footnotetext{
434. Id. at 47.

435. 8 N.E.3d 251 (Ind. Ct. App. 2014).

436. $I d$. at 253 .

437. $I d$.

438. Id.

439. Id.

440. Id.

441. Id.

442. Id.

443. Id.

444. Id.
} 
terminated due to the untimely payment of the 2012 advance royalties. ${ }^{445}$ The Company subsequently filed a quiet title action, seeking a judgment in its favor determining that the lease had expired. ${ }^{446}$ Both parties filed cross-motions for summary judgment, the trial court granted New Owner's motion for summary judgment and the Company appealed. ${ }^{447}$

The Court of Appeals concluded the lease terminated when the Company failed to timely pay the 2012 advance royalties without need of notice from New Owner. ${ }^{448}$ The Court of Appeals noted that advance royalty clauses generally fall into two categories (1) a "drill or pay" clause in which an oil company has an obligation to either commence production within a certain timeframe or pay advance royalties, and the failure to do one or the other constitutes a breach of the lease but does not automatically terminate the lease, or (2) an "unless" clause, which provides that a lease will terminate automatically unless an oil company either drills or pays advance royalties by a prescribed date. ${ }^{449}$ In this instance, the Court of Appeals found that the Advance Royalties Clause was clearly and unambiguously an "unless" clause, as after the expiration of the initial term, the lease was to continue from year-to-year if the oil company paid advance royalties in the proper amount by January 3 of each successive year. ${ }^{450}$ The Company either had the option to renew the lease by timely paying advance royalties each year or allowing the lease to expire, which "is the very essence of an "unless clause." "451 Accordingly, the Court of Appeals concluded the lease automatically terminated when the Company did not timely pay the advance royalties. ${ }^{452}$

The Court of Appeals also held the Demand Clause was not a prerequisite to termination as it explicitly stated that in addition to other termination provisions set forth in the lease, the lease would automatically terminate under certain circumstances - such as a failure to pay following demand; thus, New Owner was not required to demand payment, as the termination provisions of the Advance Royalties Clause were not subject to the Demand Clause.

\section{B. Lapse of Mineral Interests}

In Westervelt $v$. Woodcock, ${ }^{453}$ the Court of Appeals determined whether the payment of ad valorem taxes on a mineral interest prevented the lapse of such interest. ${ }^{454}$ Westervelt arose when the Kathleen A. Briggs Trust (the "Trust")

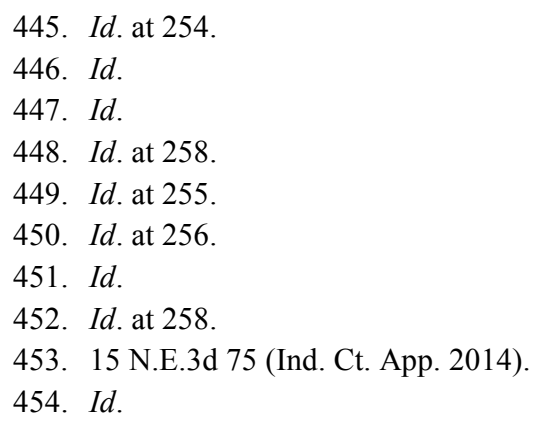


filed a quiet title action pertaining to a mineral interest in Posey County. ${ }^{455}$ At the time of the filing of the action, the Trust owned the surface rights and seveneighths of the minerals. ${ }^{456}$ After various defendants settled or were defaulted, Carolyn Sue Stinson ("Stinson") was the only remaining defendant. ${ }^{457}$ Stinson was the successor-in-interest to an individual who, via a deed from 1958, was granted mineral rights for a term of thirty years "and as long thereafter as oil and/or gas is produced from these premises or the property is being developed or operated therefor." ${ }^{558}$

Continuous production of oil had occurred on the land covered by Stinson's mineral deed, and Stinson had paid all real estate taxes that had been assessed against her mineral interest. ${ }^{459}$ Nonetheless, the Trust argued that Stinson's mineral interest had lapsed pursuant to Indiana's Dormant Mineral Act (Indiana Code section 32-23-10-2) (the "Act"), which extinguishes mineral rights that have not been "used" for the statutory period of twenty years. ${ }^{460}$ The trial court granted summary judgment to the Trust and Stinson appealed. ${ }^{461}$

The Court of Appeals concluded that Stinson's payment of taxes prevented the lapse of the mineral interest. ${ }^{462}$ At the outset, the court observed that a mineral interest is "used" for purposes of the Act when, among other possibilities, "taxes are paid on the mineral interest by the owner of the mineral interest." 463 Under Indiana law, an oil or gas interest - including royalties - is subject to assessment and taxation as real property. ${ }^{464}$ The Trust had argued that Stinson's mineral interest lapsed because her tax payments were for ad valorem taxes assessed on royalties, and the payments did not appear in the public record. ${ }^{465}$ In support of its argument, the Trust relied on Miller v. Weber ${ }^{466}$ in which the Court of Appeals previously concluded that payment of capital gains taxes on the mineral interest did not satisfy the "use" requirement of Indiana Code section 32-23-10-3(a)(6). ${ }^{467}$

The Court of Appeals, though, distinguished Miller from Stinson's interest by concluding that the Miller payment of capital gains taxes did not create a public record of ownership of the mineral interest, as capital gains taxes are not recorded in any public document. ${ }^{468}$ In this instance, Stinson paid ad valorem

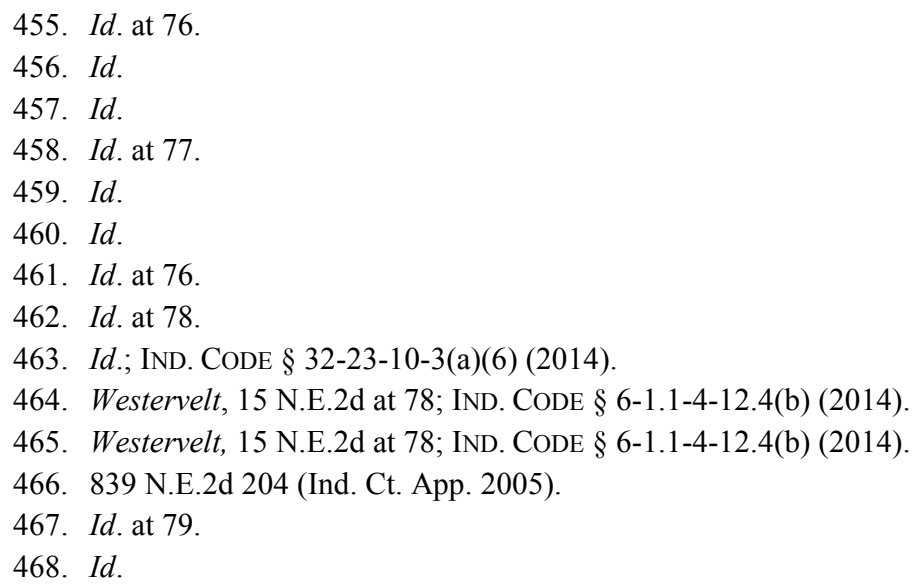


taxes that were, or should have been, recorded in public documents, as Posey County assessed taxes on Stinson's interest and generated tax statements which included identifiable information such as legal descriptions and well numbers. ${ }^{469}$ Consequently, the Court of Appeals concluded the "use" requirement of Indiana Code section 32-23-10-3(a)(6) was satisfied through payment of ad valorem property taxes and Stinson's interest was deemed not to have lapsed. ${ }^{470}$

\section{LANDLORD-TENANT}

During the survey period, the Court of Appeals published three opinions in cases concerning residential and commercial landlord-tenant issues.

\section{A. Security Deposits and Residential Leases}

In Washmuth v. Wiles, ${ }^{471}$ the Court of Appeals considered the notice requirements applicable to the seizure of residential lease security deposits. ${ }^{472}$ Washmuth arose from a lease for residential property. ${ }^{473}$ On April 1, 2013, tenant moved out of the property, but did not provide landlord with a forwarding address to which landlord was to send the security deposit and any itemized list of damages. ${ }^{474}$ On April 29, 2013, landlord and tenant exchanged text messages regarding the return of the security deposit, at which point tenant directed landlord to send the itemized list of damages to its attorney's address. ${ }^{475}$

On May 23, 2013, tenant filed a small claims court action against landlord for the return of the security deposit. ${ }^{476}$ Upon receiving tenant's address in the small claims filing, landlord mailed the itemized list of damages to tenant on May 28, 2013. ${ }^{477}$ The small claims court entered an order concluding that tenant had provided landlord with a permanent address (a post office box in the town in which the property was located) on payment checks while tenant was still in possession of the property, as well as the address of tenant's attorney, thus, triggering landlord's obligation to return the deposit with an itemized list of damages within forty-five days. ${ }^{478}$ The small claims court further determined that landlord's return was not timely and required landlord to return the entire security deposit and to pay tenant's attorney's fees. ${ }^{479}$ Landlord appealed. ${ }^{480}$

The Court of Appeals reversed, holding that landlord's forty-five day

\footnotetext{
469. Id. at 80 .

470. $I d$.

471. 12 N.E.3d 938 (Ind. Ct. App. 2014).

472. Id. at 939.

473. Id.

474. Id. at 940 .

475. Id.

476. Id.

477. Id.

478. Id.

479. Id.

480. Id.
} 
window to deliver its notice of itemized damages did not begin until tenant's text notification of his attorney's address, and rejecting the small claims court's conclusion that the post office box listed on tenant's past rental checks provided landlord with his forwarding address. ${ }^{481}$ Indiana Code section 32-31-3-12 requires a landlord to refund a security deposit, net of any damage claims provided in an itemized list, within forty-five days after termination of the rental agreement or delivery of possession to the landlord. ${ }^{482}$ The Court of Appeals observed that the post office box was used only in connection with tenant's stay at the property and that there was no evidence that this post office box remained a valid address after the lease terminated. ${ }^{483}$ Further, the Court of Appeals declined to establish an obligation for landlords to search through years of canceled checks to find a forwarding address for their tenants. ${ }^{484}$ Since tenant supplied a forwarding address on April 29, 2013, and landlord mailed the notice to tenant on May 28, 2013, landlord's notice of itemized damages was timely. ${ }^{485}$

\section{B. Duty of Care-Snow and Ice Removal}

In Pier 1 Imports (U.S.), Inc. v Acadia Merrillville Realty, L.P. ${ }^{486}$ the Court of Appeals considered the duty of care for a commercial landlord with respect to snow and ice removal from sidewalks. ${ }^{487}$ Pier 1 arose out of a retail customer's slip and fall on an ice-covered sidewalk in front of a tenant's retail store. ${ }^{488}$ The lease agreement between landlord and tenant allocated the responsibility for removing snow and ice from sidewalks to landlord. ${ }^{489}$ To satisfy this obligation, landlord had contracted with a company ("Company") to remove snow and ice from the sidewalk. ${ }^{490}$ After allegedly slipping on an ice-covered sidewalk outside of tenant's retail store, a customer sued landlord, tenant, and Company for damages related to her injuries. ${ }^{491}$ All three defendants moved for summary judgment. ${ }^{492}$ The trial court granted landlord's and Company's summary judgment motions, concluding that landlord's contract with Company and Company's use of a combined forty-five man hours to salt the sidewalk prior to the incident absolved both of any liability. ${ }^{493}$ Tenant's motion was denied, and

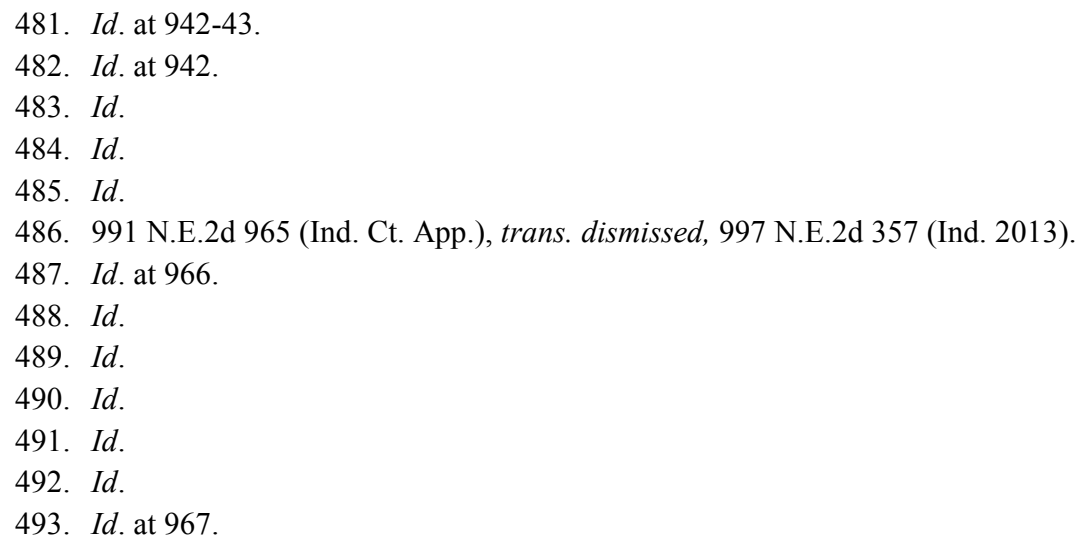


tenant appealed. ${ }^{494}$

The Court of Appeals concluded the grant of summary judgment in favor of landlord and the Company was improper as a genuine issue of material fact existed as to the scope of landlord and Company's duty of care. ${ }^{495}$ The Court of Appeals first noted that in negligence actions, summary judgment is rarely appropriate. ${ }^{496}$ Whether landlord discharged its duty of care merely by contracting with Company was a matter for the jury to decide and was not appropriate for summary disposition. ${ }^{497}$ Similarly, whether Company failed to exercise reasonable care in performing its snow and ice removal services was also a question for the jury. ${ }^{498}$ Though Company had devoted a substantial amount of time in salting the sidewalk, one of tenant's employees continued to salt the sidewalk, which raised a genuine issue of material fact as to whether Company had fully discharged its duty. ${ }^{499}$ Accordingly, the Court of Appeals reversed the trial court's summary judgment rulings. ${ }^{500}$

\section{Operating Co-Tenancy}

In Claire's Boutiques, Inc., v. Brownsburg Station Partners LLC, ${ }^{501}$ the Court of Appeals considered the interpretation of an operating co-tenancy provision in a lease. ${ }^{502}$ Claire's Boutiques arose out of a commercial landlord's ownership of a retail shopping center (the "Shopping Center"). ${ }^{503}$ The Shopping Center consisted of two large single-tenant buildings and two other buildings divided into smaller retail spaces known as Building A1 and Building A3. ${ }^{504}$ In 2007, landlord negotiated a lease with tenant for the lease of 1500 square feet of retail space in Building A3 for a term of sixty-one months. ${ }^{505}$ The lease contained an operating co-tenancy provision granting tenant the right (1) to pay percentage rent only (five percent of gross retail sales) if occupancy of the non-department retail tenants in Buildings A1 and A3 fell below seventy percent, or if Kohl's or Lowe's (or a similar anchor) failed to open for business; and (2) to terminate the lease in the event occupancy fell below the above thresholds for a period of at

494. $I d$.

495. Id. at 969-70. The Court of Appeals considered and rejected landlord's and the Company's argument that tenant lacked standing to challenge the grant of summary judgment in favor of landlord and the Company. Id.

496. Id. at 969.

497. Id. at 970 .

498. Id.

499. Id.

500. Id.

501. 997 N.E.2d 1093 (Ind. Ct. App. 2013).

502. Id. at 1095 .

503. Id.

504. Id.

505. Id. 
least one year. ${ }^{506}$ In May 2009, tenant decided to close its store in the Shopping Center for under performance, vacating the leased premises in June 2009 without notice to landlord. ${ }^{507}$ Landlord sent a default notice demanding payment of the accelerated balance of the rent. ${ }^{508}$ Tenant never responded to the notice and made no further rent payments. ${ }^{509}$ Landlord sued for breach of the lease, and both parties moved for summary judgment. ${ }^{510}$ Tenant alleged the seventy percent occupancy threshold had not been achieved for over a year, triggering tenant's right to terminate. ${ }^{511}$ The trial court determined the co-tenancy provision was ambiguous, calculated the threshold based upon the leasable square footage in Buildings A1 and A3, and concluded the termination right had not vested. ${ }^{512}$ Tenant appealed. ${ }^{513}$

The Court of Appeals held that the operating co-tenancy provision of the lease was not ambiguous; therefore, the trial court erred in concluding that the seventy percent occupancy was to be calculated as a percentage of gross leasable area rather than percentage of possible tenants. ${ }^{514}$ The Court of Appeals also held the lease did not define a method of termination and the operating co-tenancy provision did not require any notice to exercise tenant's option to terminate. ${ }^{515}$ Accordingly, the trial court erred when it held that tenant failed to properly terminate its lease by vacating the premises. ${ }^{516}$ The Court of Appeals also rejected landlord's argument that the tenant's decision to vacate was not based on the operating co-tenancy provision, but on other business considerations, since a party to a contract may defend its performance based upon a legal excuse for non-performance that existed at the time although such party was ignorant of the fact at the time. ${ }^{517}$

\section{BANKRUPTCY AND QUIET TITLE ACTIONS}

In Goodman v. Serine, ${ }^{518}$ the Court of Appeals considered the impact a bankruptcy court order has with respect to an action to quiet title to the property impacted by the bankruptcy court order. ${ }^{519}$ Goodman arose from a property

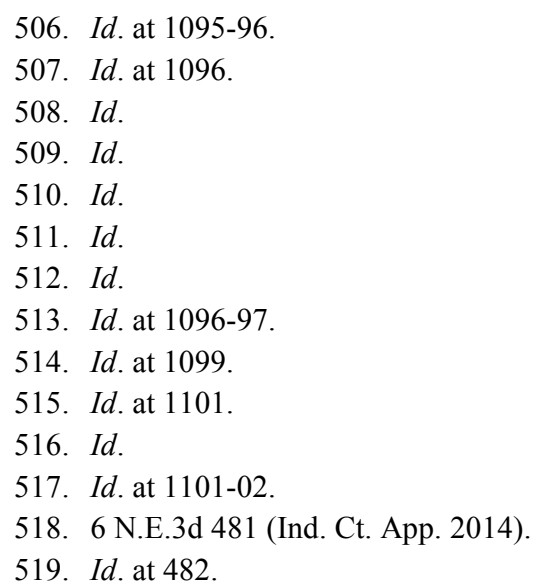


owner's failure to pay federal income taxes for 2003, 2005, and 2006. ${ }^{520}$ On March 10, 2008, the Internal Revenue Service (the "IRS") filed tax liens on the property owner's property (the "Property"). ${ }^{521}$ On July 22, 2008, the property owner filed for bankruptcy and included the Property as an asset. ${ }^{522}$ The IRS then filed a proof of claim for the unpaid taxes. ${ }^{523}$ On August 11, 2008, property owner executed a land contract for the sale of the Property to purchaser for $\$ 150,000$, with $\$ 20,000$ paid at execution and $\$ 10,000$ at a later date with the balance paid through monthly payments over a period of ten years. ${ }^{524}$ The contract clearly stated that the Property contained encumbrances, including the tax liens. ${ }^{525}$ Property owner executed the contract and delivered a quitclaim deed on the same day, but the deed was not recorded until February 1, 2010. ${ }^{526}$ On July 8, 2009, property owner filed a motion with the bankruptcy court for permission to sell the Property free and clear of any liens. ${ }^{527}$ In their motion, property owner alleged that they still owned the Property and did not disclose the sale, land contract, or conveyance. ${ }^{528}$ Additionally, property owner represented in their motion that the IRS consented to the sale of the Property. ${ }^{529}$ Property owner's motion was granted by the bankruptcy court on August 5, 2009, but no sale occurred following that date. ${ }^{530}$ Property owner's bankruptcy action was dismissed on October 1, 2009. ${ }^{531}$ Purchaser filed an action seeking to quiet title to the Property in March 2012 and named the IRS as a defendant. ${ }^{532}$ Purchaser further claimed that the IRS tax liens on the Property had been released by the bankruptcy court. ${ }^{533}$ In his motion, purchaser noted that the quitclaim deed had not been recorded until 2010 but failed to mention that the sale, land contract, and conveyance had occurred before the bankruptcy court's order clearing the tax liens and granting approval for the sale of the Property. ${ }^{534}$ Purchaser and IRS each moved for summary judgment and the trial court granted summary judgment in favor of the IRS. ${ }^{535}$ Purchaser appealed. ${ }^{536}$

The Court of Appeals determined that the trial court was not the proper

520. Id.
521. Id.
522. Id.
523. Id.
524. Id. at 483.
525. Id.
526. Id.
527. Id.
528. Id.
529. Id.
530. Id.
531. Id.
532. Id.
533. Id.
534. Id.
535. Id.
536. Id.


forum for the resolution of purchaser's quiet title action, because the sale of the Property took place during bankruptcy proceedings and was therefore subject to the bankruptcy court's jurisdiction. ${ }^{537}$ The Court of Appeals vacated the trial court's judgment and ordered the trial court to dismiss purchaser's quiet title action. ${ }^{538}$

\section{MECHANIC'S LIENS}

During the survey period, the Court of Appeals published three opinions in cases concerning mechanics' lien issues.

\section{A. Slander of Title}

In Country Contractors, Inc., v. A Westside Storage of Indianapolis, Inc. ${ }^{539}$ the Court of Appeals considered the standard to prove slander of title based on improperly filed mechanic's liens. ${ }^{540}$ Country Contractors arose out of a contractor's agreement to construct a storm sewer and other excavation work for a property owner, eventually entering into a written contract for the work. ${ }^{541}$ The contractor subcontracted with an excavator to perform most of the work. ${ }^{542}$ The excavator then hired three other companies to provide materials for the project (collectively, the "Suppliers," and together with the excavator, the "Subcontractors"). ${ }^{543}$ The contractor and excavator began work in the summer of $2008 .^{544}$ In the fall of 2008, property owner paid the contractor $\$ 191,535.72 .{ }^{545}$ During that same time, the excavator sent the contractor a total of five invoices. ${ }^{546}$ The contractor paid the first four invoices but failed to pay the fifth invoice for $\$ 38,182.23$, claiming to have never received it. ${ }^{547}$ Near the end of 2008, the contractor stopped all work on the project. ${ }^{548}$ In February 2009, the Subcontractors filed notices of intent to hold mechanic's liens on the property. ${ }^{549}$ In May 2009, the property owner paid each of the Subcontractors' mechanic's liens. ${ }^{550}$ Later that month, the contractor filed a notice of intent to

537. Id. at $483-84$.

538. Id. at 484 .

539. 4 N.E.3d 677 (Ind. Ct. App. 2014).

540. Id. at 682-83. The Court of Appeals also considered the Owner's claim to pierce Contractor's corporate veil, concluding "the trial court clearly erred in piercing the veil ...." Id. at $687-91$.

541. Id. at 692-93.

542. Id. at 682 .

543. Id.

544. Id.

545. Id.

546. Id.

547. Id.

548. Id.

549. Id.

550. Id. 
hold a mechanic's lien on the property. ${ }^{551}$ The property owner then contracted with another construction company to complete the project. ${ }^{552}$ The property owner filed a breach of contract claim against the original contractor in May 2009, alleging that it failed to complete performance and failed to pay the Subcontractors. ${ }^{553}$ In the complaint, the property owner also demanded an accounting of the payments he had made to the original contractor under the contract. $^{554}$ A trial was held in January 2013, and the property owner sought damages for breach of contract and slander of title. ${ }^{555}$ On March 11, 2013, the trial court found in favor of the property owner and awarded damages in the amount of $\$ 117,542.20 .^{556}$ The original contractor appealed. ${ }^{557}$

The Court of Appeals held that there was sufficient evidence to support the trial court's finding that the original contractor slandered property owner's title. ${ }^{558}$ In support of its holding, the Court of Appeals found that the original contractor's filing of a lien against the property owner's property was improper, because the contractor filed a lien claim when the contractor had not performed the work itself and had failed to pay the Subcontractors' invoice. ${ }^{559}$ The Court of Appeals further determined that the contractor should not have filed the lien, because it had constructive notice that the property owner had paid the Subcontractors directly, as a record of the payment was on file with the county recorder. ${ }^{560}$

\section{B. Award of Attorney's Fees}

In Goodrich Quality Theaters, Inc. v. Fostcorp Heating and Cooling, Inc., ${ }^{561}$ the Court of Appeals considered whether the trial court abused its discretion in awarding attorney's fees to certain contractors and against a general contractor pursuant to the Indiana mechanic's lien statute. ${ }^{562}$ Goodrich Quality Theaters,

551. Id.

552. Id.

553. $I d$.

554. $I d$.

555. $I d$.

556. Id.

557. Id.

558. Id. at 692-93. The Court of Appeals also considered and rejected contractor's defenses to the trial court's award of attorney's fees. Id. at 693. The Court of Appeals also determined the trial court's award of delay damages to property owner was speculative and based on inconclusive evidence. $I d$. at 699.

559. Id. at 692 .

560. Id. at 692-93.

561. 16 N.E.3d 426 (Ind. Ct. App.), aff'd on reh'g, No. 64A03-1308-PL-318, 2014 WL 7051157, at*1 (Ind. Ct. App. Dec. 15, 2014).

562. Id. The Court of Appeals also considered several other issues related to the interpretation of construction contracts and the power of a trial court to retroactively make a prior ruling a final judgment. Id. at 434-38. 
Inc. ("Goodrich") hired Roncelli, Inc. ("Roncelli") to serve as general contractor for construction of an IMAX movie theater in Portage, Indiana (the "Theater"). ${ }^{563}$ Goodrich leased the land on which the Theater was to be constructed from Spirit Master Funding III, LLC ('Spirit Master") and obtained Spirit Master's consent to construct the Theater on its land. ${ }^{564}$ Goodrich hired Paradigm Design, Inc. ("Paradigm") to create the design drawings for the Theater. ${ }^{565}$ Roncelli hired Fostcorp Heating and Cooling, Inc. ("Fostcorp"), Wilson Iron Works, Inc. ("Wilson Iron"), and Johnson Carpet, Inc. ("Johnson Carpet") as project contractors. ${ }^{566}$ Wilson Iron in turn hired Falpeg Capital, LLC, d/b/a GooderHenrichsen, Inc. ("Gooder"), and Gateway Construction as subcontractors. ${ }^{567}$ Fostcorp in turn hired Sheet Metal Werks, Inc. ("Sheet Metal") and Air Temp Mechanical ("Air Temp") as subcontractors. ${ }^{568}$ Several disputes as to completed work and payments resulted in Wilson Iron, Johnson Carpet, and Fostcorp (collectively, the "Contractors") filing mechanics liens against the Theater property. ${ }^{569}$ Litigation ensued with the Contractors seeking to foreclose their mechanic's liens. ${ }^{570}$ Based upon meritorious claims against Roncelli for failure to pay for services rendered under the various contracts, the trial court awarded Contractors their attorney's fees based upon the Indiana Mechanics Lien Statute. ${ }^{571}$ Roncelli appealed. ${ }^{572}$

The Court of Appeals concluded that the trial court abused its discretion in awarding attorney's fees against Roncelli pursuant to the Indiana mechanic's lien statute. ${ }^{573}$ The Indiana mechanic's lien statute provides that a lienholder who recovers a judgment in an action to enforce a lien under the statute is entitled to recover reasonable attorney's fees; however, a lienholder may not recover attorney's fees from a party who is not the property owner, even if the judgment is related to work performed that gives rise to the mechanic's lien. ${ }^{574}$ Since Roncelli was not the owner of the real estate or the Theater, the Court of Appeals concluded that a mechanic's lien could not be enforced against Roncelli and attorney's fees payable under the mechanic's lien statute were inapplicable. ${ }^{575}$

563. Id. at 429 .

564. Id.

565. Id.

566. Id.

567. $I d$.

568. $I d$.

569. Id. at $430-32$.

570. Id.

571. Id. at 441 (citing IND. CODE $§ 32-28-3-14$ (2014)).

572. Id. at 429 .

573. Id. at 441 .

574. Id. (citing IND. CODE $\S 32-28-3-14$ (2014)).

575. Id. 


\section{COMMON ENEMY DOCTRINE}

In Samples v. Wilson, ${ }^{576}$ the Court of Appeals considered a property owner's trespass and nuisance claims. ${ }^{577}$ Samples arose from property that Wilson owned (the "Wilson Property") with a border elevation of approximately twelve feet higher than that of the adjacent property that Samples owned (the "Samples Property"). ${ }^{578}$ Water flowed from the Wilson Property onto the Samples Property. ${ }^{579}$ In 1998, Wilson enlarged the pond and associated dam located on the Wilson Property. ${ }^{580}$ In 2003, Samples filed a complaint against Wilson, alleging trespass from water related to the construction of the dam. ${ }^{581}$ In 2006, Wilson conveyed the Wilson Property to a new owner ("New Owner"). ${ }^{582}$ In 2007, Samples amended his complaint to include New Owner and alleged that the expanded dam on the Wilson Property encroached on the Samples Property, the dam was improperly constructed, and water runoff from the Wilson Property created standing water on Samples Property. ${ }^{583}$ Samples sought an injunction to cease the encroachment and correction of the dam deficiencies and monetary damages. ${ }^{584}$ During the 2013 trial, Samples testified that a portion of the expanded dam encroached on his property and two acres of his property became swampy after the dam expansion. ${ }^{585}$ Wilson and New Owner both testified that the two acres had been periodically wet prior to the dam expansion and Samples utilized the two acres for storage and a burn area before and after the dam expansion. ${ }^{586}$ A surveyor also testified the dam did not encroach on the Samples Property. ${ }^{587}$ The trial court entered judgment in favor of New Owner. ${ }^{588}$ Samples appealed. ${ }^{589}$

The Court of Appeals upheld the trial court's ruling with respect to Samples' nuisance and trespass claim. ${ }^{500}$ On appeal, Samples had argued that the trial court's findings that the dam did not encroach upon the Samples Property were irrelevant, because the casting of water from the Wilson Property created a trespass. ${ }^{591}$ The Court of Appeals observed the "common enemy" doctrine

576. 12 N.E.3d 946 (Ind. Ct. App. 2014).

577. Id. at 948 .

578. Id.

579. Id.

580. Id.

581. Id.

582. Id. at 948-49.

583. Id. at 949.

584. Id.

585. $I d$.

586. Id.

587. Id.

588. Id.

589. Id.

590. Id. at 952 .

591. Id. at 950 . 
provides that "surface water which does not flow in defined channels is a common enemy and that each landowner may deal with it in such manner as best suits his own convenience." 592 An exception to the common enemy doctrine exists where "an owner of land has, by artificial means, thrown or cast water onto his neighbor in unusual quantities so as to amplify the force at a given point or points." 593 The evidence indicated that the dam did not throw or cast onto the Samples Property; rather, the Samples Property received natural runoff from the Wilson Property and another neighboring property. ${ }^{594}$ The Court of Appeals also determined that Samples' allegation of nuisance was not supported by evidence since testimony and an inspection performed by the Indiana Department of Natural Resources indicated that the dam was constructed with proper components, and the wetlands on Samples' land existed prior to the dam expansion. $^{595}$

\section{Mitigation of Contractual Damages}

In Fischer v. Heymann, ${ }^{596}$ the Indiana Supreme Court considered a nonbreaching party's duty to mitigate its damages from the other party's breach of contract. ${ }^{597}$ Fischer arose from a purchaser's agreement to purchase a residential condominium unit from seller for $\$ 315,000{ }^{598}$ Prior to closing, purchaser demanded that seller repair an electrical problem after an inspection report revealed three power outlets did not work. ${ }^{59}$ When seller failed to timely respond to purchaser's demand, purchaser terminated the purchase agreement, claiming that the electrical issue was a "major defect" under the purchase agreement. ${ }^{600}$ Days later, seller repaired the electrical issue for $\$ 117 .{ }^{601}$ Purchaser nonetheless refused to perform under the purchase agreement, and Seller sued for specific performance. ${ }^{602}$ Seller kept the condominium unit listed for sale, finally selling it five years later for $\$ 180,000 .{ }^{603}$ The trial court ruled in purchaser's favor, concluding that the purchaser reasonably believed the electrical problem was severe enough to justify its termination of the purchase agreement. ${ }^{604}$ On appeal, the Court of Appeals disagreed that the purchaser's belief was objectively reasonable and remanded to the trial court to determine

592. $I d$.

593. Id.

594. Id. at 951.

595. Id. at 951-52.

596. 12 N.E.3d 867 (Ind.), reh'g denied, 12 N.E.3d 867 (Ind. 2014).

597. $I d$. at 869 .

598. Id.

599. Id.

600. $I d$.

601. Id.

602. $I d$.

603. Id.

604. Id. 
damages. ${ }^{605}$

On remand, seller sought damages of $\$ 306,616.73$, which included the difference between the original contract sale price and the proceeds from the sale of the unit, along with closing costs, attorney's fees, and maintenance costs. ${ }^{606}$ The trial court entered damages in favor of seller in an amount equaling $\$ 93,972.18$ on the basis that seller failed to mitigate her damages by declining to sell the condominium in 2007 for $\$ 240,000 .^{607}$ Both parties appealed, with purchaser claiming that seller was required to mitigate her damages by timely responding to its demand for the electrical repair. ${ }^{608}$ The Court of Appeals agreed with purchaser, reducing seller's damage award to $\$ 117$ - the cost of the electrical repairs. ${ }^{609}$ Seller appealed the Court of Appeals' ruling to the Supreme Court. ${ }^{610}$

The Supreme Court overruled the Court of Appeals, finding performance beyond a non-breaching party's contractual duty is not required for it to mitigate its damages. ${ }^{611}$ Purchaser's unreasonable demand for electrical repairs and subsequent termination was a breach under the purchase agreement; accordingly, seller was not required to timely comply with the repair request, and Purchaser had no right to terminate the agreement. ${ }^{612}$ Just as breaching parties may not take advantage of their breach to relieve them of their contractual duties, neither may they take advantage of their breach to require non-breaching parties to perform beyond their contractual duties. ${ }^{613}$ The Supreme Court upheld the trial court's determination that it was unreasonable for seller to have not sold the unit in 2007 for $\$ 240,000$, as the records supported the trial court's finding. ${ }^{614}$

\section{Recovery Under the EnVIRONMENTAL Legal ACtion Statute}

In JDN Properties v. VanMeter Enterprises, Inc. ${ }^{615}$ the Court of Appeals considered the scope of liability under the Environmental Legal Actions Statute (the "ELA"). ${ }^{616}$ JDN Properties arose from a corporation's (the "Owner") ownership of a parcel of land (the "Land") ${ }^{617}$ An individual was the sole owner of the Owner ("Farmer") ${ }^{618}$ Farmer was also the president of the company that

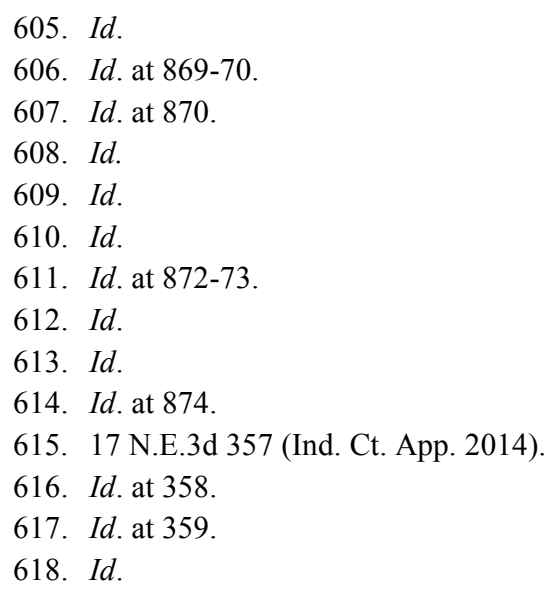


leased the Land from the Owner ("Tenant"). ${ }^{619}$ At all relevant times, Tenant operated the Land. ${ }^{620}$ Farmer hired vendor to redirect underground water lines serving the Land away from a well located near underground storage tanks ("USTs") used for petroleum heating fuel on the Land. ${ }^{621}$ Farmer subsequently died, transferring the Owner entity to Farmer's son, who had never participated in the operations of Owner or Tenant. ${ }^{622}$ Farmer's son then sold the Land to third parties who formed and transferred title to the Land to purchaser. ${ }^{623}$ Owner disclosed as part of the sale that USTs had been located on and removed from the Land but that there had never been a reportable release of any hazardous substances or petroleum. ${ }^{624}$ Years later, purchaser discovered petroleum contamination on the Land related to the USTs, which it spent significant sums to remediate. ${ }^{625}$ Purchaser then sued Owner under the ELA, which provides that "a person may, regardless of whether the person caused or contributed to the release of a hazardous substance or petroleum into the surface or subsurface soil or groundwater that poses a risk to human health and the environment, bring an environmental legal action against a person that caused or contributed to the release to recover reasonable costs of a removal or remedial action involving the hazardous substances or petroleum." ${ }^{26}$ The trial court granted Owner's motion for summary judgment. ${ }^{627}$ Purchaser appealed. ${ }^{628}$

The Court of Appeals reversed the trial court, ruling that a landlord who has knowledge that a tenant's use of land is causing environmental contamination, but does nothing to halt or remediate such contamination and sells that property to a third party without disclosing the property's condition, "contributes" to such contamination. ${ }^{629}$ In such a situation, both landlord and tenant would be potentially liable under the ELA. ${ }^{630}$ Owner presumably received rents from Tenant while being fully aware (by virtue of Farmer's ownership/control of both entities) that Tenant's use of the property was causing petroleum contamination in the ground, as demonstrated by the redirection of the water lines, thus precluding summary judgment in Owner's favor. ${ }^{631}$

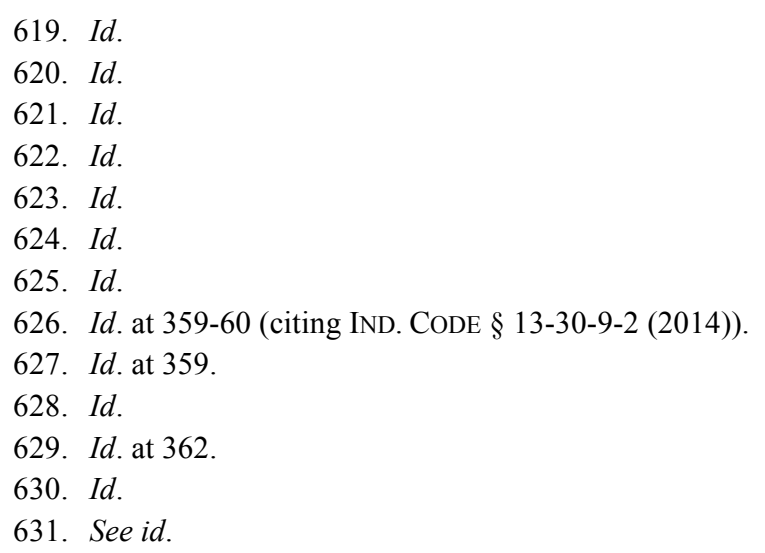




\section{ABAndonment of Mobile Homes}

In Mobile Home Management Indiana, LLC v. Avon Village MHP, LLC, ${ }^{632}$ the Court of Appeals addressed the issue of the timing requirements of the Indiana Abandoned Mobile Home Statute. ${ }^{633}$ Mobile Home Management arose from a property owner's purchase of certain property that contained mobile homes from a sheriff's sale. ${ }^{64}$ The sale did not include title to the mobile homes. ${ }^{635}$ The owner auctioned the mobile homes as "abandoned" under the Abandoned Mobile Home Statute, ${ }^{636}$ which grants a property owner the right to auction an abandoned mobile home if it has been on the property owner's property without permission for thirty days.$^{637}$ The thirty day period begins when the property owner delivers a statutorily required notice to the mobile home's owner of record. ${ }^{638}$ If the owner of record of the mobile home does not request additional time or remove the mobile home within thirty days of the first notice, the property owner is required to send a second notice by certified mail to the owner of record of the mobile home. ${ }^{639}$ The auction may be held no sooner than thirty days after the second notice's return receipt is received by the property owner. ${ }^{640}$ In Mobile Home Management, the property owner mailed both statutory notices, but did not comply with the statutorily required timeframes, conducting the auction only forty-two days after the first notice, rather than the statutory minimum of sixty days. ${ }^{641}$ The property owner purchased all the mobile homes at issue at the auction. ${ }^{642}$ Shortly after the auction, the record owner of the mobile homes sold the mobile homes to a third party. ${ }^{643}$ The property owner then filed suit for declaratory judgment to declare it the rightful owner of the mobile homes. ${ }^{644}$ The trial court denied the third party's motion for summary judgment. ${ }^{645}$ The third party appealed. ${ }^{646}$

The Court of Appeals reversed the trial court, holding that a property owner is required to strictly comply with the statutory notice requirements under the Abandoned Mobile Home Statute. ${ }^{647}$ Accordingly, the third party purchaser was

632. 17 N.E.3d 275 (Ind. Ct. App. 2014).

633. Id. at 276 (citing IND. CODE $\S 9-22-1.5-1$ (2014)).

634. Id. at 277.

635. Id.

636. Id. at 278 (citing IND. CODE $\S 9-22-1.5-1$ (2014)).

637. Id. at 279 (citing IND. CODE $\S 9-22-1.5-2$ (2014)).

638. Id. (citing IND. CODE $\S 9-22-1.5-3$ (2014)).

639. Id. (citing IND. CODE $§ 9-22-1.5-4$ (2014)).

640. Id.

641. Id. at 280 .

642. Id. at 277.

643. Id. at 278 .

644. $I d$.

645. Id.

646. Id.

647. Id. at 280 . 
the title holder to the mobile homes. ${ }^{648}$

\section{ZONING}

During the survey period, the Court of Appeals published two opinions in cases concerning the interpretation and application of zoning ordinances.

\section{A. Exhaustion of Administrative Remedies}

In Barnette v. US Architects, LLP ${ }^{649}$ the Court of Appeals considered whether a declaratory judgment action challenging a zoning determination and denial of a variance should be dismissed for failure to exhaust administrative remedies. ${ }^{650}$ Landowners ("Owners") retained an architect ("Architect") to design an accessory building on their residential lot. ${ }^{651}$ Owners submitted plans to the Carmel Department of Community Services ("DCS"), which ultimately issued a building permit and subsequent certificate of occupancy. ${ }^{652}$ Several months after the accessory building was built, Owners' neighbors complained to DCS that Owners' accessory building violated building height restrictions in the Carmel Zoning Ordinance. ${ }^{653}$ DCS sent Owners a letter stating that the DCS had determined that the building permit had been issued in error, advising Owners to file for a design standards variance. ${ }^{654}$ Owners did not appeal DCS's determination that their accessory building exceeded height restrictions under the Carmel Zoning Ordinance to the Carmel Board of Zoning Appeals ("BZA") pursuant to Indiana Code section 36-7-4-918.1. ${ }^{655}$ However, Owners did apply for a variance on the advice of and with the assistance of DCS, which was denied by the BZA. ${ }^{656}$ Owners did not appeal the denial of variance by the BZA. ${ }^{657}$ DCS sent a second letter to Owners stating that the certificate of occupancy was being withdrawn and providing Owners with sixty days in which to remodel the accessory building. ${ }^{658}$ Owners did not appeal this determination. ${ }^{659}$ Instead, Owners and Architect (collectively, "Plaintiffs") filed a complaint against the City of Carmel ("City") for a declaratory judgment seeking interpretation of the Carmel Zoning Ordinance provision applicable to building height requirements for the accessory building. ${ }^{660}$ City, and the neighbor who intervened in the

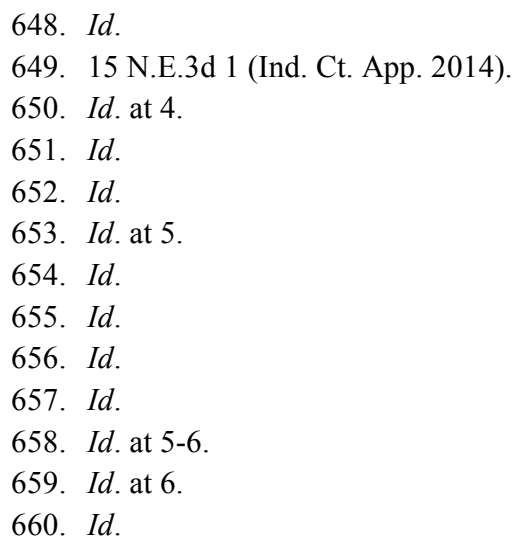


matter, contended that Plaintiffs had not exhausted their administrative remedies. ${ }^{661}$ Plaintiffs asserted that DCS had violated their due process rights by effectively revoking their certificate of occupancy without a hearing and asserted estoppel as an affirmative defense. ${ }^{662}$ The trial court held that Plaintiffs' failure to exhaust administrative remedies would have been fatal to their claims but for two reasons: (1) DCS's violation of Owners' due process rights in revoking the certificate of occupancy without a hearing, and (2) DCS should be estopped from revoking the certificate of occupancy issued because Owners had reasonably relied (to their detriment) on the issuance of the building permit and certificate of occupancy only to be told almost six months after construction was completed that the accessory building did not comply with the Carmel Zoning Ordinance. ${ }^{663}$ The neighbors appealed, but City did not. ${ }^{664}$

The Court of Appeals concluded that Owners' failure to exhaust their administrative remedies left the trial court without subject matter jurisdiction and so reversed the trial court's ruling and remanded with instruction to dismiss Owners' complaint. ${ }^{665}$ The Court of Appeals first established that, as a general rule, where "an administrative remedy is available, filing a declaratory judgment action is not a suitable alternative." ${ }^{\prime 66}$ The Court of Appeals observed that this general rule applies even where the basis of the complaint is the unconstitutionality of a statute, which may be beyond the agency's power to resolve, because administrative remedies may be able to resolve the issue without reaching the constitutional question. ${ }^{67}$ The Court of Appeals acknowledged that an exception to the general rule exists "when some equitable consideration precludes its application," ${ }^{668}$ but concluded that the trial court erred when it determined that Plaintiffs had satisfied the elements of a claim of equitable estoppel and were therefore excused from exhausting their administrative remedies prior to filing suit. ${ }^{669}$ The Court of Appeals also rejected Plaintiffs' due process claims, concluding that, after failing to take advantage of opportunities to appeal the DCS determinations and the BZA denial of the requested variance, Owners could not claim to have been denied due process. ${ }^{670}$

661. Id.

662. Id.

663. Id. at 7.

664. Id. at 8 .

665. Id.

666. Id. at 9 (citing Carter v. Nugent Sand Co., 925 N.E.2d 356, 360 (Ind. 2010)).

667. Id.

668. Id. at 10 (citing Smith v. State Lottery Comm'n of Ind., 701 N.E.2d 926, 931 (Ind. Ct. App. 1998)).

669. Id. at 11 .

670. $I d$. 


\section{B. Interpretation of a PUD Ordinance}

In Brookview Properties, LLC v. Plainfield Plan Commission, ${ }^{671}$ the Court of Appeals considered the Plainfield Plan Commission's ("PPC") interpretation of a PUD ordinance. Brookview Properties concerned a property owner's plan to develop apartments under the name Hearthview Metropolis on twenty-five acres of property within the Metropolis PUD (the "Hearthview Parcel"). ${ }^{672}$ The Metropolis PUD was originally conceived of as a mixed-use project to be developed in phases by a single developer. ${ }^{673}$ The property owner acquired the Hearthview Parcel at a sheriff's sale following foreclosure against the original developer of the Metropolis PUD. ${ }^{674}$ In July 2012, the property owner filed for approval of a PUD Preliminary Plan and a PUD Final Detailed Plan that provided for the development of apartments on the Hearthview Parcel. ${ }^{675}$ At a public hearing on the property owner's petition, the PPC heard comments for and against the Hearthview Metropolis project. ${ }^{676}$ At the hearing, the property owner took the position that although the original preliminary plan encompassing the Hearthview Parcel (the "Original Plan") that contemplated multi-family use of the Hearthview Parcel had expired, the uses permitted under the Original Plan remained approved uses. ${ }^{677}$ Accordingly, the PPC's authority was limited to approving the property owner's proposed development standards ${ }^{678}$ At the end of the hearing, PPC denied the property owner's petition, finding that the proposed Hearthview Metropolis project was not appropriate for the surrounding area because (1) additional multi-family units would add to the existing imbalance of housing types in Plainfield, (2) the project did not address the remaining undeveloped areas within the original PUD area, (3) the project was not consistent with the original intent of the PUD, and (4) the design of the project was inconsistent with the design of the Metropolis PUD. ${ }^{679}$ The property owner filed petition for judicial review of the PPC's denial of its petition. ${ }^{60}$ The trial court affirmed the PPC denial of the property owner's petition. ${ }^{681}$ Property owner appealed. ${ }^{682}$

The Court of Appeals considered four issues: (1) whether the PPC exceeded its authority when it denied the development plan, (2) whether the PPC's findings were adequate, (3) whether the PPC's decision violated the property owner's

671. 15 N.E.3d 48 (Ind. Ct. App. 2014).

672. Id. at 55 .

673. Id.

674. Id.

675. Id.

676. $I d$.

677. Id.

678. Id.

679. Id. at 57.

680. Id.

681. Id.

682. Id. 
substantive and procedural due process rights, and (4) whether the PPC's decision constituted an unconstitutional taking without just compensation. ${ }^{63}$ The Court of Appeals affirmed the trial court's ruling as to all four issues. ${ }^{64}$ First, the property owner contended that PPC's sole function in reviewing its petition was to consider the proposed development plans according to the prescribed development standards for multi-family housing. ${ }^{655}$ The property owner argued that the power to re-zone land is with the Town Council, not the PPC, and PPC's denial amounted to a change in the underlying PUD zoning ordinance. ${ }^{686}$ The Court of Appeals rejected the argument, concluding that the Metropolis PUD did not establish a land use for the Hearthview Parcel, in part because no primary plan designating a land use, let alone a multi-family use, had been approved with respect to the Hearthview Parcel. ${ }^{67}$ As such, the trial court did not err in concluding that the PPC had the authority to reject a proposed multi-family use for the Hearthview Parcel. ${ }^{68}$

Second, the property owner argued that the PPC's findings were insufficiently detailed, in particular that certain of the PPC's findings were mere general statements tracking the language of the ordinance. ${ }^{689}$ Indiana Code section 36-7-4-1406(a) requires that plan commissions issue written findings of each decision to allow for adequate judicial review. ${ }^{690}$ Findings should include specific, concrete reasons for each decision, and should not be raised piecemeal, so that a petitioner can attempt to amend their petition to comply with the ordinance being applied. ${ }^{691}$ Findings of a plan commission are insufficient if they are merely a general recitation of the requirements of the ordinance at issue. ${ }^{692}$ The Court of Appeals read the PPC's findings as sufficiently detailed to provide the property owner with notice of the reasons for the PPC's denial. ${ }^{693}$

Third, the property owner argued that the PPC's denial of its petition on the ground that multi-family use was approved under the Metropolis PUD was without legitimate basis, and beyond the PPC's discretion, and was therefore a denial of due process. ${ }^{694}$ Because the evidence supported the PPC's determination that the Metropolis PUD did not designate any land use for the Hearthview Parcel, the Court of Appeals rejected the property owner's

683. Id. at 58-66.

684. Id.

685. Id. at 58 .

686. Id.

687. Id. at 59-60.

688. Id. at 60 .

689. Id. at 61 .

690. Id.

691. Id. (citing The Kroger Co. v. Plan Comm'n of the Town of Plainfield, 953 N.E.2d 536, 543 (Ind. Ct. App. 2011)).

692. Id.

693. Id. at 65 .

694. Id. 
argument. $^{695}$

Fourth, the property owner argued that it acquired the Hearthview Parcel with the knowledge and expectation that multi-family use was approved under an existing preliminary plan, and that the PPC's denial constituted a taking without just compensation. ${ }^{696}$ The Court of Appeals rejected this argument, concluding that because no preliminary plan had been approved for the Hearthview Parcel, the property owner could not have had any expectation concerning a specific land use of it. ${ }^{697}$

\section{Common Law Dedication to Governmental Units}

In Lagro Township $v$. Bitzer, ${ }^{698}$ the Court of Appeals considered the circumstances under which language in a deed establishing a cemetery can effectuate a public dedication to a governmental unit. Lagro Township arose out of a property owners' deed of one acre of "real estate in Wabash County to 'the public' to be used as a cemetery." ${ }^{\prime 299}$ The one acre parcel was located on a larger 219-acre parcel of land that was later purchased by the Bitzers ("Owners") in 1967. ${ }^{700}$ From the time that Owners purchased the 219 acres in 1967, Lagro Township (the "Township") never contacted them about the cemetery or otherwise attempted to maintain the cemetery. ${ }^{701}$ In 2006, the Wabash County Assessor assigned the cemetery its own tax identification number for the first time, showing the cemetery as exempt from property tax; however, the cemetery's legal description and acreage on the tax records were misidentified so the exempt acreage was never deducted from Owners' property taxes. ${ }^{702} \mathrm{In}$ 2009 , Owners cleared the cemetery area except for the two headstones of the original landowners. ${ }^{703}$ Shortly thereafter, the Township's Trustee (the "Trustee") conducted an investigation and concluded that Owners had desecrated the cemetery. ${ }^{704}$ The Township then brought a quiet title action to establish the Township's interest in preserving the cemetery and to recover damages from Owners. ${ }^{705}$ The trial court granted Owners' motion for summary judgment and the Township appealed.

The Court of Appeals concluded that the Township did not have statutory control over the cemetery. ${ }^{706}$ Though the Township correctly stated that

695. Id. at 65-66.

696. Id. at 66 .

697. Id.

698. 999 N.E.2d 902 (Ind. Ct. App. 2013).

699. Id. at 902 .

700. $I d$.

701. Id. at 903.

702. Id.

703. Id.

704. Id.

705. Id.

706. Id. at 907 . 
Indiana's General Cemetery Law grants townships the responsibility to locate and maintain certain cemeteries that are without funds for maintenance (Indiana Code section 23-14-68-3), the Court of Appeals noted that the statute is inapplicable to cemeteries located on land on which property taxes are assessed and paid. In this instance, the cemetery property was misidentified in the county's tax records. ${ }^{707}$ As a result, Owners had paid taxes on all of their land, including the cemetery property, without deduction or exemption since $1967 .{ }^{708}$ Accordingly, the Court of Appeals upheld the trial court's decision even though "there was a genuine issue of material fact with regard to whether and to what extent the dedication of [the cemetery] to the public was accepted by the public through usage." 709 